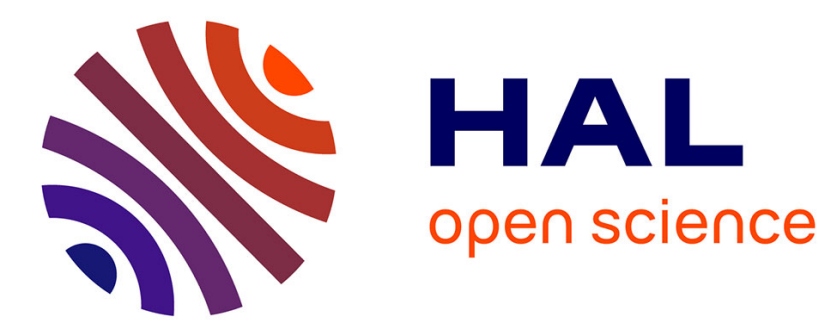

\title{
Risk sharing from international factor income: explaining cross-country differences
}

\author{
Vadym Volosovych
}

\section{To cite this version:}

Vadym Volosovych. Risk sharing from international factor income: explaining cross-country differences. Applied Economics, 2011, 45 (11), pp.1435-1459. 10.1080/00036846.2011.617703 . hal00768584

\section{HAL Id: hal-00768584 \\ https://hal.science/hal-00768584}

Submitted on 22 Dec 2012

HAL is a multi-disciplinary open access archive for the deposit and dissemination of scientific research documents, whether they are published or not. The documents may come from teaching and research institutions in France or abroad, or from public or private research centers.
L'archive ouverte pluridisciplinaire HAL, est destinée au dépôt et à la diffusion de documents scientifiques de niveau recherche, publiés ou non, émanant des établissements d'enseignement et de recherche français ou étrangers, des laboratoires publics ou privés. 


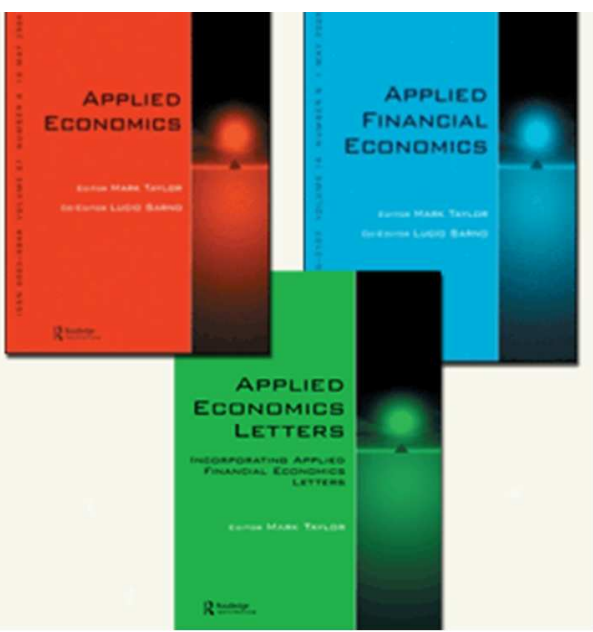

\section{Risk sharing from international factor income: explaining cross-country differences}

\begin{tabular}{|c|c|}
\hline Journal: & Applied Economics \\
\hline Manuscript ID: & APE-2011-0031.R1 \\
\hline Journal Selection: & Applied Economics \\
\hline $\begin{array}{l}\text { Date Submitted by the } \\
\text { Author: }\end{array}$ & 21-Aug-2011 \\
\hline Complete List of Authors: & $\begin{array}{l}\text { Volosovych, Vadym; Erasmus University Rotterdam, Business Economics } \\
\text { (Finance) }\end{array}$ \\
\hline JEL Code: & $\begin{array}{l}\text { F36 - Financial Aspects of Economic Integration < F3 - International } \\
\text { Finance < F - International Economics, G15 - International Financial } \\
\text { Markets < G1 - General Financial Markets < G - Financial Economics, O17 } \\
\text { - Formal, Informal Sectors; Shadow Economy, etc. < O1 - Economic } \\
\text { Development < O - Economic Development, Technological Change, and } \\
\text { Growth }\end{array}$ \\
\hline Keywords: & $\begin{array}{l}\text { risk sharing, diversification, international financial integration, investor } \\
\text { protection }\end{array}$ \\
\hline
\end{tabular}

\section{SCHOLARONE"}

Manuscripts 


\title{
Risk sharing from international factor income: explaining cross-country differences
}

\author{
Vadym Volosovych* \\ Erasmus University Rotterdam, Tinbergen Institute and ERIM
}

August 2011

\begin{abstract}
Access to world capital markets and net investment income flows between countries help protect national income from country-specific output shocks. I empirically study what factors explain cross-country differences in the extent of risk sharing from international factor income. An index of investor protection is the leading causal variable for the estimated amount of risk sharing over the 1985-2004 period. Improving investor protection in Russia to Denmark's level implies five times larger risk sharing compared to the sample average. These results indicate one possible way to reap large potential benefits from international risk sharing.

JEL Classification: F36, G15, O17
\end{abstract}

Keywords: Risk sharing, diversification, international financial integration, investor protection

\footnotetext{
*Burg. Oudlaan 50, Room H14-30, 3062 PA Rotterdam, the Netherlands; e-mail: volosovych@ese.eur.nl. I thank Jean Imbs, Sebnem Kalemli-Ozcan, Ayhan Kose, Gian Maria Milesi-Ferretti, David Papell, Eswar Prasad, Bent Sorensen, Andrey Ukhov, Kei-Mu Yi, and an anonymous referee for their comments and suggestions.
} 


\section{Introduction}

Economists usually assume that people dislike uncertainty of consumption. One way to reduce cross-sectional variability in consumption levels is to diversify the sources of income. Access to world capital markets helps diversify among a larger number of assets and locations compared to the hedging of risk in domestic capital markets. At the country level, ownership of foreign assets partially insulates national income from country-specific economic shocks (terms-of-trade changes, policy shocks, fluctuations in production, natural disasters, and so on) and improves consumption smoothing. ${ }^{1}$ What explains countries ability to diversify and share risk in world markets? I empirically demonstrate that domestic investor protection is the leading explanation for differences in international income smoothing in a large sample of developing and industrialized countries.

The dramatic increase in gross stock of foreign assets and liabilities with relatively small net positions in the 1990s-2000s is often associated with growing asset diversification between countries (Obstfeld and Taylor, 2004). In theory, representative individuals would trade claims to each others' endowments in complete international asset markets and fully eliminate idiosyncratic risk (Obstfeld and Rogoff, 1996), which would bring large theoretical welfare gains (Van Wincoop, 1994; Tesar, 1995). Looking back at the recent world financial crisis, we need to challenge this conventional view and ask ourselves what explains the observed effects of financial liberalization, such as capital flight, volatile capital flows, global imbalances, and unstable domestic financial markets, and why in practice countries obtain less than full risk sharing (see Broner and Ventura, 2010; Lewis, 1999; Kose et al., 2009 for surveys). Kenneth Rogoff in his recent column agrees that "we are very far from the idealized world in which financial markets efficiently share risk. Of the roughly \$200 trillion in global financial assets today, almost three-quarters are in some kind of debt instrument [...]. The derivatives market certainly helps spread risk more widely than this superficial calculation implies, but the basic point stands" and urges us to "recognize that the real problems [connected to the sustained large global imbalances] are rooted in excessive concentrations of debt. If G-20 governments stood back and asked themselves how to channel a much larger share of the imbalances into equity-like instruments, the global financial system that emerged just might be a lot more robust

\footnotetext{
${ }^{1}$ In the literature smoothing of national income against output shocks is referred to as "income risk sharing," "income smoothing," or "income insurance." I use the three terms interchangeably. I refer to the difference between country-level and the world-wide variables as "country-specific" or "idiosyncratic."
} 
than the crisis-prone system that we have now.” (see Rogoff, 2011).

I focus on risk sharing directly related to diversification in world asset markets, which is just one possible mechanism of consumption smoothing at the country level (the other being intertemporal smoothing through adjustment of savings). Risk sharing through cross-ownership of productive assets deserves a special attention. This channel best approximates a hypothetical complete markets environment, while "the degree of risk shifting that loan markets permit is generally far inferior to what truly complete asset markets would allow" (Obstfeld and Taylor, 2004, p.9 and Rogoff, 2011 mentioned above). Non-contingent international loans (world credit markets) can smooth only temporary income drops (Baxter and Crucini, 1995), access to international borrowing is not readily available to many countries because of sovereign risk (Obstfeld and Rogoff, 1996) and the history of defaults (Reinhart et al., 2003; Reinhart and Rogoff, 2004), or the lenders may be reluctant to provide credit to countries hit by a persistent negative shock. ${ }^{2}$ Risk sharing through factor income should be the most effective channel in international setting. ${ }^{3}$ Because of the recent surge in size of country foreign portfolios it also must be the easiest to detect. We need more empirical evidence on the determinants of this channel.

The basic intuition of this paper comes from the theory of international risk diversification and trade in risky assets outlined by Obstfeld and Rogoff (1996). To motivate my empirical analysis, I present a simple $N$-country extension of the model of Heathcote and Perri (2004) and demonstrate that a higher country risk raises the demand for international insurance while higher barriers to cross-border capital flows are associated with lower insurance. These general implications are consistent with the the literature that nevertheless remains silent on which theoretical barriers matter empirically. I address this question using the data for one hundred and seventeen countries over the 1985-2004 period. I use two empirical models developed by the literature. The first empirical model ("Model 1") involves two steps. First, I build on Obstfeld (1994b) and Sorensen and Yosha (1998) and use gross national income (GNI) and GDP data and measure international income risk

\footnotetext{
${ }^{2}$ Leibrecht and Scharler (2011) show that adjustment of consumption growth to output shocks is asymmetric, and countries smooth the impact of adverse shocks on consumption faster than the impact of positive shocks. This result is consistent with the interpretation that borrowing constraints become binding relatively quickly after negative shocks and thereby reduce a countrys ability to smooth consumption.

${ }^{3}$ In addition, Balli and Sorensen (2007) find a negligible extent of consumption smoothing through central fiscal institutions and private transfers (such as remittances) even for advanced countries. Canova and Ravn (1996) and Artis and Hoffmann (2008) argue that the observed lack of international risk sharing may be due to a lack of insurance against permanent shocks.
} 
sharing obtained by individual countries. ${ }^{4}$ Second, I regress the estimated extent of risk sharing on various proxy measures of the barriers, controlling for a measure of country output risk. This cross-sectional approach allows me to empirically investigate the role of a number of theoretical barriers, including those with little time variation. An alternative empirical model ("Model 2") is conceptually similar to the first step of the previous method but utilizes panel dimensions of the data as in Melitz and Zumer (1999) and Sorensen et al. (2007).

I find a substantial cross-country variation in the estimated extent of risk sharing. For example, the risk sharing estimate is $2-4$ percent for Brazil or Lithuania in contrast to $13-14$ percent for Poland and Costa Rica and 51 for Switzerland (100 percent means full risk sharing). The crosssection regressions (Model 1) show that an index of investor protection is positively related to the measured country income insurance. This index is a broad measure of the country's attitude regarding inward investment and assesses the risks of contract viability and expropriation, profits nonrepatriation, and payment delays. The proxies for other cross-border barriers are of second-order significance. The results are robust to the sample split by the degree of financial openness, controlling for other potential determinants of risk sharing, and possible endogeneity bias. I establish a causal and economically significant effect of investor protection on income risk sharing through instrumental variables analysis. The empirical estimates imply that moving from the lowest quartile in the index of investor protection (a country like Russia) to the highest quartile (a country like Denmark) should result in fivefold improvement in the extent of risk sharing over the sample mean. The dynamic panel regressions (Model 2) confirm that countries with better investor protection on average have more international risk sharing, increasing investor protection goes hand-in-hand with increasing risk sharing, and this effect becomes stronger over time.

This paper makes several contributions. First, unlike the recent studies focusing on consumption risk sharing (as Kose et al., 2009; Fratzscher and Imbs, 2009) or volatility of consumption (as Bekaert et al., 2006) I explore a channel of risk sharing associated with international asset diversification and factor income flows. This is one well-defined channel of the overall consumption smoothing known in the risk sharing literature since Asdrubali et al. (1996). The consumption-

\footnotetext{
${ }^{4}$ The measure relies on a cross-sectional decomposition of GDP as in Asdrubali et al. (1996) and reflects the sensitivity of national income (GNI per capita) to idiosyncratic output (GDP per capita) fluctuations. It potentially varies from 0 (no risk sharing) to 100 percent (full risk sharing) and represents a percentage of idiosyncratic risk to GDP insured through net factor income flows (compared to full risk sharing). We can obtain negative empirical estimates of the measure that would imply dis-smooting of income; see details in Section 3.
} 
based studies blend several potential mechanisms besides the contribution of foreign income. For example, financial integration, through competitive pressure on domestic markets and governments (Rajan and Zingales, 2003; Gourinchas and Jeanne, 2006), may also improve risk sharing from saving or tax-transfer system. Still, the present paper is not inconsistent with the papers (most notably Fratzscher and Imbs, 2009) that consider openness to world goods and capital markets as a "channel" by which institutions affect total risk sharing. ${ }^{5}$ My channel is different. I identify an "international diversification" channel of risk sharing obtained through hedging in world capital markets. GNI-based risk sharing measure also helps eliminate a number of data issues recognized in the empirical literature (puzzles in consumption behavior, "taste shocks," and so on). In Appendix $\mathrm{B}$, I provide suggestive evidence that investor protection is also correlated with the degree of consumption risk sharing. Because of the issues with international consumption data (see Deaton and Heston, 2010) and a variety of mechanisms by which overall risk sharing is obtained these results should be taken with a grain of salt.

Second, this paper relates to the literature that views cross-border capital flows not as a complement but as an outcome of institutional quality (see Alfaro et al., 2008). I add to this literature by showing that international risk sharing is also affected by a more primitive institutional determinant, the degree of investor protection. This result is consistent with the fact that the extent of risk sharing is much larger within countries, where institutions are similar, than between countries. ${ }^{6}$

Third, the positive empirical relationship between investor protection and international income risk sharing establishes a missing link between the financial development and risk sharing literatures and points to a direction for the regulatory reform. Weaker investor rights hamper risk sharing in world asset markets. Recently, Broner and Ventura (2010) demonstrated that the level of development, the depth of domestic financial markets, and the quality of institutions affect the volatility of capital flows and stability of domestic financial markets in a model environment resembling actual global financial markets around the time of financial crisis of 2007-2008. My results imply that the negative effect through financial markets underdevelopment (La Porta et al., 1997, 1998; Glaeser and Shleifer, 2002) seems to dominate the positive "bonding" effect by which firms may es-

\footnotetext{
${ }^{5}$ Fratzscher and Imbs concentrate on consumption risk sharing between pairs of countries and establish the positive interaction effect of institutions and trade openness for their definition of risk sharing. They also document that effect of good institutions is larger in a sub-sample of more financially open countries.

${ }^{6}$ Crucini (1999); Sorensen and Yosha (1998); Kalemli-Ozcan et al. (2003); Becker and Hoffmann (2006); and Asdrubali and Kim (2008) document lower risk sharing between countries than within countries.
} 
cape environments with poor or ineffective investor protection through "bonding" with international markets (Karolyi, 2004; Claessens et al., 2006; Claessens and Schmukler, 2007). ${ }^{7}$ I also add to the discussion on the design of institutional arrangements that promote international risk sharing. ${ }^{8}$ The European Union provides an example of how fast political, economic, legal, and regulatory integration could improve the member-countries' investment climate and promote integration of their capital markets. This in turn would lead to higher risk sharing and long-run economic growth. ${ }^{9}$

In the following Section 2, I discuss conceptual issues motivating the empirical analysis. In Section 3, I describe the empirical measures of financial integration and barriers to capital mobility. Section 4 presents the empirical results. Section 5 concludes.

\section{Conceptual issues}

\subsection{Defining risk sharing through factor income flows}

The risk sharing literature typically concentrates on smoothing of consumption against output fluctuations because in theory and in practice consumption risk sharing is the ultimate goal. A branch of research originated by Asdrubali et al. (1996) and Sorensen and Yosha (1998) focuses on "channels" of risk sharing and examines the contribution of these channels to "total" consumption risk sharing. ${ }^{10}$ Individuals can share risk with others in well-functioning financial markets through cross-ownership of financial assets ("capital market" channel) and through borrowing and lending ("credit market" channel). Central fiscal institutions (or a tax-transfer system) provide further income smoothing by lowering taxes for and increasing transfers and grants to individuals, regions, and countries that experience economic hardships. ${ }^{11}$ Asdrubali and Kim (2008) stress the interac-

\footnotetext{
${ }^{7}$ The examples of "bonding" are customized contracts and corporate charters with larger rights for investors than as required by the local law, listing companies in countries and on exchanges with better investment regime, or merger with the foreign companies.

${ }^{8}$ In international context, Robert Shiller proposed a scheme under which countries in a risk-sharing pool could issue claims on their output, Robert Merton advocates a network of GDP swaps executed bilaterally or by an intermediary (see Borensztein and Mauro, 2004 for a review). A multinational fiscal federation which smoothes income cross-sectionally is advocated by Forni and Reichlin (1999) for Europe.

${ }^{9}$ With insurance against asymmetric output shocks people can specialize and safely engage in riskier but high-return investment projects and guarantee higher expected consumption growth and welfare, speed up capital accumulation, financial deepening, and reduce uncertainty in the growth process (Helpman and Razin, 1978; Obstfeld, 1994a; Acemoglu and Zilibotti, 1997; Kalemli-Ozcan et al., 2003; and Imbs, 2004).

${ }^{10}$ The reader is invited to refer to Asdrubali et al. (1996) for details.

${ }^{11}$ The European Union (EU) Structural Funds and the Cohesion Fund are examples of an international tax-transfer system that may contribute to risk sharing. The Funds are the financial instruments of the EU regional policy. They intend
} 

Gross National Product. Gross National Saving in the formula above is loosely defined to include depreciation, international transfers, and net saving (by governments, businesses, and individuals).

${ }^{13}$ The SNA puts concept of residence—not nationality or citizenship—as the basis of accounting. A resident within the economic territory engages in economic activities on a significant scale over a long period of time (usually one year or more). For more details, refer to the revised System of National Accounts 1993 (United Nations, 2005).

${ }^{14}$ The remittances are the current transfers in cash or in kind by resident migrant workers to their country of origin. Because of SNA's residency emphasis, remittances are excluded from NFI of the workers' home countries. For example, a Polish citizen earning income in the UK as a British resident would contribute to the UK's GNI; her remittances to Poland are not included in factor income flows to Poland. Instead, these transfers enter the secondary distribution of income account and do affect the level of Poland's Gross National Disposable Income. 


\subsection{Costs and benefits of international risk sharing: an analytical framework}

To motivate the empirical analysis, I sketch a conceptual relationship between a measure of risk sharing introduced by Asdrubali et al. (1996) and the costs and benefits of risk sharing. According to Lewis (1999), this is one of the most general ways to think about risk sharing. ${ }^{15}$ Define the idiosyncratic component of output as $\tilde{y}_{t} \equiv y_{t}-y_{t}^{w}$ where $y_{t}$ and $y_{t}^{w}$ represent the growth rate output of a country and the world in period $t$, correspondingly; $\tilde{c}_{t} \equiv c_{t}-c_{t}^{w}$ is defined similarly using the income or consumption data, depending on application. Subtracting the world growth in period $t$ is important because the world output fluctuations cannot be diversified away. It is convenient to express the actual degree of risk sharing as the extent to which $\tilde{c}_{t}$ is immune to changes in $\tilde{y}_{t}: \beta=1-\frac{\operatorname{Cov}\left(\tilde{c}_{t}, \tilde{y}_{t}\right)}{\operatorname{Var}\left(\tilde{y}_{t}\right)}$. With full risk sharing, country-specific output shocks are not reflected in its income (full income risk sharing) or consumption (full consumption risk sharing) resulting in $\operatorname{Cov}\left(\widetilde{c}_{t}, \widetilde{y}_{t}\right)=0$ and $\beta=1$.

General Setup. Assume the world of $N$ open atemporal economies populated by representative individuals who maximize expected utility, are endowed with a single non-storable good, and have the same preferences. ${ }^{16}$ The output endowment is uncertain and depends on a state of nature $s \in \mathcal{S}$. The realization of uncertainty is similar for all people within a country (there is no risk sharing within a country). Each country's uncertain endowment $y_{j}(s)$ follows the process consisting of two state-dependent parts: world common factor $w(s)$ and a country-specific factor $z_{j}(s)$ : $y_{j}(s)=w(s)+z_{j}(s)$, where $j=1$ is the country index. The distribution of country endowment $y_{j}(s)$ is perfectly symmetric across countries and same for all people within a country. Countryspecific factor $z_{j}(s)$ is i.i.d. across countries and is independent from the world factor $w(s)$ and foreign country-specific factors $z_{i}(s), i \neq j$. Given these assumptions, countries' endowments are correlated because of the global component, but imperfectly due to country-specific effects. Domestic endowment uncertainty creates incentive to diversify. Only country-specific portion of endowment volatility $\left(\operatorname{Var}\left[z_{j}(s)\right]=\sigma_{z}^{2}\right)$ can be eliminated by diversification.

At the start of each period, before uncertainty is resolved, $j$ 's resident retains a fraction $\chi_{j}$ of domestic endowment and acquires $\chi_{i}^{f}$ claims on the endowment other countries $i$ in global asset

\footnotetext{
${ }^{15}$ The literature often tends to discuss the costs and the benefits of risk sharing separately. Lewis (1999) postulates that the international risk sharing might be small because the costs to diversification exceed the benefits involved. This implies that both factors should be analyzed simultaneously.

${ }^{16}$ I do not consider non-separability between consumption and leisure and non-tradable endowment because these frictions does not seem to explain low international risk sharing (see Lewis, 1999).
} 
market. At this level of abstraction, I follow Canova and Ravn (1996) and take no stand on what decentralization scheme supports the optimal risk sharing allocations (the existence of equity markets in each country; contingent claim markets where countries trade claims to each others endowments; or some other arrangements which implement optimal allocations even when international financial markets are absent). Cross-border capital mobility involves "frictions." A resident in country $j$ receives only a fraction $1-\tau$ of any income flows from abroad (this approach to model border frictions is used by Gordon and Bovenberg, 1996; Heathcote and Perri, 2004; Martin and Rey, 2004, and many others). Personal income consists of domestic endowment people retain and their stakes in the other countries' endowment: $m_{j}(s)=\chi_{j} y_{j}(s)+(1-\tau) \sum_{i \neq j} \chi_{i}^{f} y_{i}(s)$.

After the state of nature $s$ is observed people consume the income $m(s)$ they receive-no further adjustment is possible by portfolio reallocation or by saving and borrowing. ${ }^{17}$ In some cases, such consumption behavior is fully consistent with the "rule-of-thumb" consumers of Campbell and Mankiw (1989), who simply set consumption equal to income in each period: $c_{j}(s)=m_{j}(s)$. For a variety of reasons (liquidity constraints, adjustment costs, "near-rational" consumer behavior, subsistence constraints) the proportion of the "rule-of-thumb" consumers in developing countries, especially among subgroups of households that are poor, is likely to be much higher (Ravallion and Chaudhuri, 1997; Jalan and Ravallion, 1999; Gerry and Li, 2010). In addition, downplaying the intertemporal consumption smoothing is valid because the present paper focuses on the diversification channel.

Because of ex ante symmetry across countries, in equilibrium an individual is indifferent between holding claims to only domestic endowment and the pool of claims to domestic and foreign endowment: $P_{j}=\chi_{j} P_{j}+\sum_{i \neq j} \chi_{i}^{f} P_{i}$. With the purchasing power parity condition $P_{j}=P_{i} \forall i$, the $j$ 's representative individual purchases identical shares of claims to foreign endowments: $\chi_{i}^{f}=\chi^{f} \forall i$. Portfolio choice constraint simplifies to $1=\chi_{j}+(N-1) \chi^{f}$, country $j$ 's claims on each foreign country's endowment $\chi^{f}=\frac{1-\chi_{j}}{N-1}$, and the individual budget constraint is:

$$
c_{j}(s)=\chi_{j} y_{j}(s)+(1-\tau) \frac{1-\chi_{j}}{N-1} y_{j}^{*}(s), \forall s, j
$$

\footnotetext{
${ }^{17}$ Heathcote and Perri (2004) show that under certain conditions_-also fulfilled in my model_-people who can reallocate the portfolio each period choose the same allocations as in one-period model with a single trade. Since people optimally choose not to reallocate their portfolios after the initial period it is safe to assume that they cannot do this.
} 
where $y_{j}^{*}(s)$ is the rest of world (ROW) endowment for country $j . y_{j}^{*}(s)$ is the aggregate uncertain endowment of all the countries but $j: y_{j}^{*}(s)=\sum_{i \neq j} y_{i}(s)$. This consumption choice holds for all countries by the symmetry assumption and guarantees global market clearing: $y^{w}(s)=$ $c^{w}(s)+\tau(1-\chi) y^{w}(s), \forall s$. In any state of nature $s \in \mathcal{S}$ the total world endowment (including all $N$ countries) is equal to the sum of the world consumption $c^{w}(s)$ and the loss in international transactions $\tau(1-\chi) y^{w}(s)$.

Individual Portfolio Choice. Denote $v(m)$ the individual indirect utility conditional on having received income $m$. I suppress the country index $j$ and the state of nature index $s$ to simplify notation. Because there is no intertemporal borrowing and lending and income and consumption are the same, $v(m)=u(c)$, where $u(c)$ denotes the period utility of consumption. Each period the individual chooses the share $\chi$ of domestic endowment in portfolio to solve the problem $\max _{\chi} E[v(m)]=\max _{\chi} E[u(c)]$, subject to the budget constraint in the Eq. (1) and the constraint precluding short positions in foreign shares, $\chi \leq 1 .{ }^{18}$ The other countries' equilibrium shares in individual portfolio are given by $\chi^{f}=\frac{1-\chi}{N-1}$. The Kuhn-Tucker optimality conditions for this problem are $E\left[u^{\prime}(c) y\right]=\frac{1-\tau}{N-1} E\left[u^{\prime}(c) y^{*}\right]+\lambda$ and $\lambda(1-\chi)=0 ; u^{\prime}$ is the derivative with respect to $\chi$, and $\lambda \geq 0$ is the Lagrange multiplier of the inequality constraint. The expression $E\left[u^{\prime}(c) y\right]$ can be thought of as the marginal utility gain of an infinitesimal shift in consumption source toward domestic endowment $y$. Expression $\frac{1-\tau}{N-1} E\left[u^{\prime}(c) y^{*}\right]$ is the marginal utility gain associated with a shift toward consuming a unit more out of the pooled ROW endowment $y^{*}$ net of the loss $\tau$. Portfolio choice involves a tradeoff. On one hand, given endowment uncertainty, relying more heavily on domestic endowment as the source of income is more risky. The incentive to diversify and rely more on the pooled world endowment rises with endowment uncertainty. On the other hand, shifting the income source to foreign endowment $y^{*}$ involves a variety of costs, which are represented by a proportional "tax" $\tau$ on the inflows of foreign investment income.

International Diversification in Equilibrium. The problem has two solutions depending on the value of $\lambda$. A strictly positive value of $\lambda$ implies $E\left[u^{\prime}(c) y\right]>\frac{1-\tau}{N-1} E\left[u^{\prime}(c) y^{*}\right]$ and the short-selling constraint binds. The solution is $\chi=1$ : the individual holds $100 \%$ of her own endowment and zero

\footnotetext{
${ }^{18}$ Taking a short position in foreign shares in the beginning of the period means that the individual promises to deliver more than what she owns before trade, or $100 \%$ of their own endowment when $\chi=1$. Restricting $\chi$ to be no greater than one in the constraint (1) rules out such possibility. This, seemingly restrictive, assumption is not unreasonable if we remember that many developing countries cannot indeed borrow short or without collateral.
} 
of the ROW endowment, or does not diversify internationally $(1-\chi=0)$. This corner solution occurs in equilibrium because the loss of income caused by the $\operatorname{tax} \tau$ while consuming a marginally higher portion the pooled ROW endowment $y^{*}$ is too high; the expected marginal utility benefit from consuming slightly more of home endowment (left-hand side of the inequality) is larger.

When $\lambda=0, \chi$ is less than one, and the first order condition has the form $E\left[u^{\prime}(c) y\right]=$ $\frac{1-\tau}{N-1} E\left[u^{\prime}(c) y^{*}\right]$. The individual is indifferent between two sources of income on the margin. Assuming for concreteness that all people maximize exponential utility $u(c)=-\frac{1}{A} e^{-A c}$ and that $y$ and $y^{*}$ are drawn from bivariate Normal distribution, the solution for the equilibrium extent of international diversification $1-\chi$ by the representative individual takes the form:

$$
1-\chi=\max \left[\frac{\tau-\frac{\tau \mu_{y}}{A \sigma_{w}^{2}}+\phi}{\tau^{2}+\left[\frac{(1-\tau)^{2}}{N-1}+1\right] \phi}, 0\right]
$$

Here $\mu_{y} \equiv \mathrm{E}[y]$ is the average country endowment, $\phi \equiv \sigma_{z}^{2} / \sigma_{w}^{2}$ is the variance of idiosyncratic portion of endowment $\sigma_{z}^{2}$ relative to the world $\sigma_{w}^{2}$. A higher value of $\phi$ means the higher diversifiable country-specific risk relative to un-diversifiable global risk.

This simple model delivers implications consistent with the richer models and with the empirical regularities discovered in the literature. First, with no cross-border barriers, individual country consumption moves one-to-one with the world endowment (the usual full risk sharing result holding for a broad class of preferences; see Obstfeld and Rogoff, 1996, pp. 300-304). Second, risk sharing is related to the degree of home bias in asset portfolios (shown empirically by Sorensen et al., 2007; Artis and Hoffmann, 2008). Third, small border frictions can lead to a substantial equity home bias, as in the model Obstfeld and Rogoff (2000). Lower barriers or higher uncertainty about domestic output creates an incentive to diversify globally (e.g., Heathcote and Perri, 2004; Martin and Rey, 2004). Most importantly, the framework provides clear testable implications for the extent of risk sharing that I bring to the data.

Risk Sharing in Equilibrium. Define the idiosyncratic portion of endowment $\tilde{y} \equiv y-\frac{y^{*}}{N-1}$ and income $\tilde{c} \equiv c-\frac{c^{*}}{N-1}$ where, as before, $y^{*}$ and $c^{*}$ are the ROW endowment and consumption. After calculating $\operatorname{Cov}(\tilde{y}, \tilde{c})$ and $\operatorname{Var}(\tilde{y})$ it is easy to show that the extent of income insurance $\beta=$ 
$1-\frac{\operatorname{Cov}(\tilde{c}, \tilde{y})}{\operatorname{Var}(\tilde{y})}$ is a simple function of the extent of diversification in equilibrium $1-\chi$ :

$$
\beta=(1-\chi)\left(1+\frac{1-\tau}{N-1}\right)
$$

Figure 3 illustrates the intuition behind the Eq. (3) from a simulated model. ${ }^{19}$ The extent of risk sharing $\beta$, from 0 (no risk sharing) to $100 \%$ (full risk sharing), is depicted in the vertical axis; the other axes show cross-border barriers $\tau$ and domestic endowment uncertainty $\phi$. Holding domestic endowment risk constant, a lower barrier $\tau$ (moving down along OX axis) leads to a larger degree of insurance in equilibrium, up to full insurance $\beta=100 \%$ when $\tau \rightarrow 0$ (as in Lewis, 1996). A higher domestic risk relative to the global risk (moving up along OY axis) creates an incentive to diversify and is associated with better insurance (larger $\beta$ ) in equilibrium, all else equal. This comparative static analysis helps interpret the coefficients in a cross-sectional regression such as:

$$
\text { COUNTRY RISK SHARING } i=\text { constant }+\gamma_{0} \text { RISK }_{i}+\text { BARRIERS }_{i}^{\prime} \gamma
$$

A lower intensity of barriers to foreign investment and a higher domestic risk are associated with a greater degree of international risk sharing.

\subsection{Barriers associated with national borders}

The theoretical sketch in the previous section is very abstract and does not say what the cost parameter $\tau$ might reflect. The literature suggests a number of frictions which might limit risk sharing. Lewis (1996) stresses the importance of legal restrictions to cross-border capital flows. The negative effects of asymmetric information in capital markets, such as adverse selection, moral hazard, or costly state verification, are well-documented..$^{20}$ Despite recent advances in information technology and rapidly declining costs of acquiring and transmitting information, investors living outside the country might still have inferior knowledge of the local conditions and return opportunities. Limited enforcement of contracts across borders makes repayment of debt dependent on the borrower's

\footnotetext{
${ }^{19}$ I choose values of the free parameters that are consistent with international business cycles literature (see for example Backus et al., 1992; Heathcote and Perri, 2004): $\mathrm{A}=1, \mu_{y}=2$, and $\sigma_{z}=0.02$; these values generate a percentage standard deviation of the common factor, $\sigma_{w}$, of $1 \%$.

${ }^{20}$ Information asymmetries could lead to the reversal of capital flows (as in the model of Gertler and Rogoff, 1990), explain differences in real interest rates across countries (Gordon and Bovenberg, 1996), financial asset returns, home bias and risk sharing (Martin and Rey, 2004). Portes and Rey (2005) empirically stress importance of imperfect information and other credit market imperfections for bilateral equity flows.
} 
willingness to pay, rather than ability to pay. Sovereign default risk is especially problematic and might be "the most fundamental reason why international capital markets may be less integrated than domestic capital markets" (Obstfeld and Rogoff, 1996). ${ }^{21}$ Obstfeld and Rogoff (2000) theoretically demonstrate that small "iceberg shipping costs" (interpreted as tariff and non-tariff goods market restrictions) may be responsible for low international risk sharing, among other "puzzles" in international macroeconomics. Martin and Rey (2004) model the asset "transaction costs" similarly and interpret them as banking commissions, exchange-rate transaction costs, and some information costs. Finally, the financial literature associates the extent of international hedging of risk with the degree of investor protection, but there are different views on how these variables are related. One prospective is that better protection of shareholders and creditors improves risk sharing through financial markets development (La Porta et al., 1997, 1998; Djankov et al., 2003, 2008) and promoting the international diversification and risk-taking by local entrepreneurs (Stulz, 2005; Doidge et al., 2004; Schmukler and Vesperoni, 2006). From a different prospective, firms may escape environments with poor or ineffective investor protection through "bonding" with international markets (Karolyi, 2004; Claessens et al., 2006; Claessens and Schmukler, 2007). Consequently, the effect of investor protection on risk sharing is ambiguous. Next, I explore which theoretical barriers are empirically relevant for the "diversification" risk sharing.

\section{Empirical methodology and data}

\subsection{Empirical specifications}

I use two linear empirical models to explore which cross-border frictions, if any, matter for risk sharing, controlling for domestic output risk. The first empirical specification (Model 1) builds on Obstfeld (1994b) and Sorensen and Yosha (1998):

$$
\begin{aligned}
\widetilde{g d p}_{i t}-\widetilde{z}_{i t} & =\nu_{i}+\beta_{i} \widetilde{g d p_{i t}}+\varepsilon_{i t} . \\
\widehat{\beta}_{i} & =\text { constant }+\gamma_{0} \operatorname{RISK}_{i}+\text { BARRIERS }_{i}^{\prime} \gamma+X_{i}^{\prime} \delta+\epsilon_{i} .
\end{aligned}
$$

\footnotetext{
${ }^{21}$ Tirole (2002) stresses that government actions can affect private willingness or ability to fulfill international contracts. When a government assumes private debt it becomes sovereign debt. Reinhart et al. (2003) and Reinhart and Rogoff (2004) demonstrate that a country's default history explains its ability to withstand high risk of default and borrow internationally.
} 
and consists of individual-country time-series regressions in Eq. (5) and a cross-sectional regression in Eq. (6). Here the variable $\widetilde{g d p}_{i t}$ represents the idiosyncratic part of output calculated as GDP per capita growth rate of country- $i$ in period $t$ minus the world per capita GDP growth: $\widetilde{g d p}_{i t} \equiv$ $\Delta \log g d p_{i t}-\Delta \log g d p_{t}^{\text {World }}$. The variable $\widetilde{z}_{i t}$ is defined similarly using GNI data. By using GNI to estimate $\beta$, I match the empirical measure with the theoretical model of international diversification in Section 2 and isolate the international capital market channel of risk sharing (income risk sharing). In contrast, to measure the combined contribution of all (international and domestic) channels of risk sharing to total consumption risk sharing one would use consumption data for $\widetilde{z}_{i t}$ (see Obstfeld, 1994b; Lewis, 1996). The coefficient $\widehat{\beta}_{i}$ directly quantifies the fraction of idiosyncratic risk to a country $i$ 's GDP insured through factor income flows, compared to full risk sharing. Full risk sharing implies that idiosyncratic shocks to GDP and GNI are uncorrelated, and $\widehat{\beta}_{i}=1$ or 100 percent, when multiplied by 100. I subtract the aggregate component from the growth rates because the world fluctuations (or systematic risk) cannot be insured (Obstfeld, 1994b also controls for some uninsurable factors such as world oil shocks). RISK is the estimate of country risk, BARRIERS is the vector of proxies for cross-border frictions, and $X$ is the vector of other covariates, all calculated as averages over time. Notice that measurement errors in the estimates of $\widehat{\beta}$ do not bias the regression coefficients in Eq. (6) since such errors end up in the error term $\epsilon_{i}$.

I interpret the results from the Eq. (6) as the effects on risk sharing over the long-run. In practical terms, this specification allows me to study a number of measures of barriers, including those with missing data for some years, variables with little or no time variation, or pre-sample variables. The disadvantage of this two-step approach is a potential loss of efficiency because the estimation of dependent variable $\widehat{\beta}$ uses relatively few observations. Alternatively, I take advantage of both dimensions of the data and estimate the following panel regression (Model 2):

$$
\widetilde{g d p}_{i t}-\widetilde{g n i}_{i t}=\text { constant }+\beta \widetilde{\beta g d p}_{i t}+\varepsilon_{i t} .
$$

This regression is similar to the first-step estimation of $\widehat{\beta}$ in Eq. (5), but allows $\beta$ to vary with 
country characteristics through the following structure: ${ }^{22}$

$$
\beta=\beta_{0}+\beta_{1}\left(\operatorname{RISK}_{i t}-\overline{\operatorname{RISK}}_{i}\right)+\left(\text { BARRIERS }_{i t}-\overline{\operatorname{BARRIERS}}_{i .}\right) \beta_{2}+\beta_{3}(t-\bar{t})
$$

As before, $\widetilde{g d p}_{i t}$ is the growth rate of country real per capita GDP minus the growth rate of the "world" GDP; $\widetilde{g n i}_{i t}$ is defined similarly using the growth rate of real per capita GNI. The estimate of $\beta_{0}$ represents the average amount of risk sharing within a group of countries during the timeperiod, and the other $\beta$ s measure the amount of risk sharing obtained in period $t$ by country $i$ with its values of interaction variables. Time trend $t$ captures the possibility of risk sharing increasing over time for reasons not captured in the empirical model. As Demyanyk et al. (2007), I demean the variables in the interaction terms by their un-weighted averages across countries at time $t$ to keep the interpretation of $\beta_{0}$ invariant to inclusion or exclusion of interaction terms. ${ }^{23}$

\subsection{Estimates of income risk sharing for individual countries}

Over the last thirty years countries' external assets and liabilities as a ratio of GDP increased almost eightfold for industrialized economies, and from three times for liabilities to seven times for assets within emerging market economies. A steep upward trend in financial globalization is apparent in the mid-1980s and continued to accelerate throughout the 1990s (IMF, 2005, Fig. 3.1). I focus on the time period beginning in 1985 , both because this is the period when one can expect to find non-negligible risk sharing in world capital markets and because of data availability for a number of emerging market economies. The largest Whole World sample consists of 117 industrialized, emerging market, and developing economies with available estimates of income risk sharing and the data for the main explanatory variables. To estimate Eq. (5), I use GDP and GNI per capita

\footnotetext{
${ }^{22}$ Melitz and Zumer (1999) introduce the structure where the extent of risk sharing $\beta$ can vary by country. My approach closely follows Sorensen et al. (2007) and Demyanyk et al. (2007) who allow for interactions of risk sharing with multiple explanatory variables. Usually it is hard to obtain a balanced panel with a large number of explanatory variables without making the restrictive assumptions about missing data.

${ }^{23}$ As discussed by Demyanyk et al. (2007), when the interaction terms are not included in the regression in Eq. (7), $\beta_{0}$ approximately measures the amount of risk sharing at the average values of the variables RISK and BARRIERS. If the interaction terms are included but not demeaned, $\beta_{0}$ would represent the amount of risk sharing when RISK=0 and BARRIERS $=0$. I subtract the middle year of the sample period $\bar{t}$ from time trend $t$ for the same reason.
} 
in 1995 U.S. dollars. ${ }^{24,25}$ In addition, I adjust for possible serial correlation in errors using the Cochrane-Orcutt procedure and drop countries with "abnormally" high and low estimates of risk sharing (top and bottom 2.5 percent in terms of $\widehat{\beta}_{i}$ ). ${ }^{26}$

Table 1 reports the point estimates of $\widehat{\beta}_{i}$; they are plotted graphically in Figure 1 , together with a $95 \%$ confidence interval. One quarter of the countries have a negative $\widehat{\beta}_{i}$; the rest of the point estimates indicate some risk sharing. On average, the extent of income risk sharing is around $2 \%$ in this sample (the first row of Table 2). There is no a priori restriction on the sign of the empirical estimate of $\beta$. In theory, the negative values imply that idiosyncratic GNI responds more than oneto-one to idiosyncratic GDP_-there is "dis-smoothing" of income relative to output. ${ }^{27}$ Another possibility is the presence of a measurement error, by which the estimated $\widehat{\beta}_{i}$ is related to the "true" $\beta_{i}$ via expression $\widehat{\beta}_{i}=\beta_{i}+$ measurement error $_{i}$. Figure 1 indeed shows that the country-level estimates of the "true" $\beta$ are not always very precise and the standard error band is often wide. Which of these two possibilities holds true and to what extent is unknown. For the purposes of the present study, what matters is the cross-country variation in $\widehat{\beta}_{i}$, which I intend to explain by estimating Eq. (6), rather than the particular values of $\widehat{\beta}_{i}$. Table 2 shows that the cross-sectional variation in these estimates is extensive: the sample standard deviation is an absolute 9.4 percent, while the minimum is $-18 \%$ (Egypt) and the maximum is $31 \%$ (Czech Republic). The measurement error in $\beta$ is a random variable, possibly correlated with observable country characteristics. The estimates of the coefficients in model (6) will not be biased because the unexplained portion of the measurement error will end-up in the residual term $\epsilon_{i}$.

\footnotetext{
${ }^{24}$ In context of risk sharing one benchmark is the autarky equilibrium when countries consume the value of their GDP. A natural measure of output is then GDP deflated by the CPI, not by a GDP deflator. I recalculate the nominal GDP and GNI data in local currency from the World Bank into real 1995 U.S. dollars using the Consumer Price Index (CPI) and U.S. dollar exchange rate for 1995. This translates GDP and GNI per capita to the amount of individual consumption that they can buy.

${ }^{25}$ In empirical study it is impossible to calculate the true whole world total GDP and GNI aggregates. The empirical notion of the world includes 23 high-income OECD countries by the World Bank classification that on average account for $80 \%$ of total GDP of my largest empirical sample.

${ }^{26}$ They are obvious outliers Luxembourg and Switzerland with large net savings abroad (the estimates of $\widehat{\beta}_{i}$ for these two economies are $44 \%$ and $51 \%$, respectively). The rest of outliers include several poor, hyperinflationary, or war-ridden developing countries. They are Albania, Bangladesh (low $\widehat{\beta}_{i}$ ), and Burkina Faso, Namibia, Nicaragua, Nigeria, Papua New Guinea, Sierra Leone, and Suriname (high $\widehat{\beta}_{i}$ ). I also employ least absolute deviation regressions to check the role of outliers in driving the main findings.

${ }^{27}$ Even though the illustrative example in Section 2 rules out these possibilities I keep the countries with negative estimates of $\beta$ in my main sample to exploit all available information in the empirical analysis.
} 


\subsection{Measuring domestic output risk and cross-border barriers}

I proxy for the country risk (demand for risk sharing) by the ratio of the standard deviation of individual-country GDP per capita growth over time to that of the world (the variable Output Risk). Notice that the country risk variable reflects (diversifiable) idiosyncratic, (non-diversifiable) global components of output, and some random noise whereas the extent of risk sharing $\beta$ is a non-linear function of just the idiosyncratic component of output so Output Risk and $\beta$ would not be related "by construction." On average, the country risk is 6 times larger than the "world" risk, and the maximum is 33 times for Angola (second row of Table 2). I expect the coefficient of Output Risk to be positively significant to reflect an incentive to diversify internationally.

The following variables serve as empirical proxies of the barriers to risk sharing, with the expected sign in brackets and the descriptive statistics in the remainder of Table 2. Appendix A describes the data and the variables in detail. Legal Restrictions on Trade and Capital Flows () are measured by the average of four 0-1 variables from the IMF's Annual Report on Exchange Arrangements and Exchange Restrictions, which indicate presence of special foreign exchange arrangements, restrictions on current and capital transactions, and repatriation requirements for export proceeds. The average score for De Jure External Restrictions is around 0.5; the range is from 0 (no government restrictions) to 0.99 for Syria (full ban on external transactions). Sovereign Risk (-): I draw on Reinhart et al. (2003) and Reinhart and Rogoff (2004) and construct the Historical Sovereign Defaults variable equal to the number of defaults since the early nineteenth century. While the average number of defaults in the Whole World sample is around 2, Turkey and a number of Latin American countries defaulted 7-8 times! Asymmetric Information (-): Distance is a natural proxy for asymmetric information costs featured in gravity models from trade literature (see, for example, Frankel and Romer, 1999). Following the approach of Kalemli-Ozcan et al. (2003), I construct a variable called Distantness that is a weighted average of the distances from the capital city of a particular country to the capital cities of the other countries using the GDP shares of the other countries as weights. The average value of Distantness is around 7.8 thousand $\mathrm{km}$, with smaller values for the Western European countries and the largest for remote countries in Oceania. ${ }^{28}$ In-

\footnotetext{
${ }^{28}$ The GDP weights capture the positive relation between trade volume and GDP. As explained in Alfaro et al. (2008, p.13), this variable is a proxy not for geography (like "distance from equator" and average distance between countries) but rather for information frictions. Because of the GDP weights, out of two equally remote countries based on average distance, the one which is "smaller" economically would be in a greater disadvantage.
} 
vestor Protection ( + or - ) is proxied by an investor protection index from the International Country Risk Guide's (ICRG) data set of political safety variables by the PRS Group (2004). Investor Protection averages ratings according to the risks of contract viability/expropriation, profit repatriation, and payment delays - a broad set of risks that constitute "investment profile" of a given country. ${ }^{29}$ The variable ranges from 0 to 10 with a higher score implying a lower risk. The average score for the investor protection index is 5.9 (the last row of Table 2) corresponding to, for example, Costa Rica, Greece, or Tunisia. The range is from 2.6 (for Myanmar and Haiti) to 8.4 (for Estonia and Slovenia). Interestingly, the "rich" OECD members, with the highest values found in this index at 7.2-7.4, do not fare as well as a number of emerging markets.

\section{Empirical Results}

\subsection{Evidence from a two-equation Model 1}

Histograms suggest that Output Risk and Distantness should be logged to reduce the impact of outliers. The correlations of Output Risk with the measures of barriers is not very high to make the estimation of the separate effects infeasible (see Table 2) except for maybe the negative correlation of Investor Protection with De Jure External Restrictions and Distantness (about -0.5). I estimate the multiple regression in Eq. (6) over a reasonably large sample to guard against potential multicollinearity problem. ${ }^{30}$ Table 3 reports the main results of this paper based on the main Whole World sample of 117 economies listed in Table 1 and the model in Eq. (5)-(6). In all of the OLS regressions, the dependent variable is the estimate of income risk sharing $\widehat{\beta}_{i}$, a constant term is included, and possible heteroskedasticity of an unknown form is corrected using White's method. Column 1 of Table 3 shows that Output Risk is insignificant at conventional levels. Columns 2-5 report the results of bivariate OLS regressions of the estimates of income risk sharing $\widehat{\beta}_{i}$ on the logarithm of Output Risk and four candidate measures of cross-border barriers separately. Prox-

\footnotetext{
${ }^{29}$ ICRG names this index "Investment Profile." PRS Group claims that ICRG ratings are immune to the "perception bias" because they do not rely on opinion surveys of any kind, in particular on opinion surveys of businesses operating in a particular country. I address these issues further in instrumental variables analysis.

${ }^{30}$ I calculate a condition index as in Belsley (1991) and variance inflation factors (see Kennedy (1998)) to evaluate the severity of multicollinearity. The condition index introduced by Belsley (1991) equals to the square root of the largest eigenvalue divided by the smallest eigenvalue of the data matrix. When there is no collinearity at all, the eigenvalues and the condition index will all be equal to 1 . When the multicollinearity increases, the eigenvalues get close to zero the condition index rises. Belsley advises that when the condition index is larger than 30 , the multicollinearity is a serious concern.
} 
ies for government restrictions, sovereign/default risk, and investor protection are significant with expected signs, but a proxy for information friction is insignificant. In a multiple regression with all four measures of barriers (column 6) the coefficient of Investor Protection remains positive and significant (p-value of 7\%). Only a marginal effect of explicit government controls ( $p$-value of just $16 \%$ ) supports the evidence of inefficiency of legal controls in preventing financial integration. The coefficients of Historical Sovereign Defaults and Distantness are negative but insignificant. The latter is probably the sign of decline in asymmetric information problems with recent advances in information dissemination technology. In all specifications Output Risk remains insignificant.

I estimate the multiple regressions with Investor Protection and the other three measures of barriers one at a time in order to explore whether multicollinearity prevents distinguishing the separate effects of the barriers. In all of the specifications, Investor Protection remains highly significant, while proxies for the other barriers do not. The stability of the coefficient for Investor Protection along with the value of the condition index for these regressions suggest that the multicollinearity is not a problem. ${ }^{31}$ These results hold with alternative measures of other barriers to capital mobility and (more weakly) with other proxies of institutions. The data "prefers" the proxy for investor protection. ${ }^{32}$ Thus, I proceed with the specification including Output Risk and Investor Protection. The $R^{2}$ of this regression (column 5, Table 3 ) indicates that about $6 \%$ of the variation in the risk sharing estimates is associated with variation in these two variables. The partial correlation plot of the estimates of risk sharing versus Investor Protection controlling for the effect of Output Risk in Figure 2 does not reveal any noticeable outliers. ${ }^{33}$ Countries with better investor protection obtain more risk sharing, on average.

IV analysis. Gourinchas and Jeanne (2006), Rajan and Zingales (2003), and Kose et al. (2006) postulate that financial integration can put pressure on countries to improve their institutions and policies (such as the government policies toward firms), in particular create investor-friendly environment. Plus, Investor Protection may partially capture the effect of other omitted variables that

\footnotetext{
${ }^{31}$ Only in the regression with Output Risk and the measures of all four barriers the condition index is 46 , which points to a severe multicollinearity.

${ }^{32}$ I experiment with all indices from ICRG (for example, law and order, quality of bureaucracy, corruption) and index of corruption from Transparency International. The coefficient of Investor Protection comes out most significant, stable, and largest in absolute value in all specifications. I attempt to differentiate between different aspects of institutions in the robustness section.

${ }^{33}$ It plots the residuals from the OLS regression of $\widehat{\beta}_{i}$ on Output Risk versus the residuals from the regression of Investor Protection on Output Risk in the main sample. By the Frisch-Waugh theorem, the coefficient in that regression is 2.18, exactly the same as the coefficient of Investor Protection in the multiple regression in column 5, Table 3.
} 
are correlated with investment protection and have a direct effect on the extent of risk sharing. ${ }^{34}$ Reverse causality and omitted variables may potentially bias the OLS estimates of Investor Protection upwards. If, on the contrary, the index corresponds to a subset of factors important for people who diversify risk internationally or includes the risks that are easy to escape, the proxy would cause regression "attenuation" and bias the OLS coefficient downwards. I estimate the empirical model in Eq. (6) using Two-Stage Least Squares (2SLS) with the investor protection index treated as endogenous and instrumented in the first stage in an attempt to reduce these biases. ${ }^{35}$ Table 4 presents the results. Panel B reports the results of the second stage regressions. Column 1 confirms evidence from La Porta et al. (1998): the legal origin is important for today's degree of investor protection. To shed some light on the broad concept of "investor protection" and suggest a possible direction for policy reform I use the proxies for minority investor rights as alternative instruments. The large literature that followed La Porta et al. stresses that the way minority shareholders are treated gives you the best indication on the overall investment climate in a country. La Porta et al. (1999a) argue that the development of today's minority investor rights happened over time by gradual selection, adaptation of best practices, or sometimes imitation. ${ }^{36}$ Therefore, this concept is narrower and, according to La Porta et al. (1999a), determined in a relatively distant past. In columns 2-3 I use the indices of minority shareholder protection by corporate codes against director misuse of corporate assets for personal gain (Shareholder Rights), liability of executives for damages to the company (Director Liability), and shareholder ability to sue officers and directors for misconduct (Shareholder Suits). Protection of minority shareholders indeed contributes to better overall protection of investors. ${ }^{37}$ In all regressions high Output Risk negatively affects investment protection in the first stage. The second stage regressions in panel A show a positive and significant effect of Investor Protection on risk sharing. I test and confirm that my instruments have no effect on risk sharing besides

\footnotetext{
${ }^{34}$ Then the OLS procedure would erroneously "assign" the effect of the omitted variables to institutions. I addressed this problem, at least partially, by running multiple regressions with the investor protection index and other controls. In addition, a rating agency may observe an economy actively engaging into international risk sharing and assign better investment protection score to the country.

${ }^{35}$ The 2SLS regressions including other barriers besides Investor Protection do not change the qualitative results in this section.

${ }^{36}$ In Britain, the courts became fairly independent from the crown since as early as 17th century and, under the pressure of the parliament, protected private property and later investors. On the continent, the state dominated the courts or property owners. Today's commercial codes in France and Germany, adopted by Napoleon and Bismark in 19th century, preserved more limited investor rights. Since then, different variations of these three systems spread throughout the world.

${ }^{37}$ I obtain similar results with a measure of the efficiency of the judicial (or administrative) system in the collection of overdue debt. The systems with complex and cumbersome court procedures hurt investors.
} 
through their effect on this index (the "exclusion restriction"). The significance of the instrumented variable is lower (a usual for the 2SLS) but on an absolute value the 2SLS estimates are larger than the OLS counterparts reported in panel C. The downward "attenuation" bias must have dominated the other OLS biases. Level of investor protection seems to be a causal variable for income risk sharing in the 1985-2004 period. Its effect is also economically significant. According to the 2SLS estimates, moving from the lowest to the highest quartile in the index (from a country like Russia to a country like Denmark) should improve risk sharing from the average of 2 percent to as much as 10 percent. $^{38}$

Tables 5 and 6 focus on robustness. In general, the effect of investment protection on risk sharing is robust to splitting the samples, the inclusion of other measures of barriers to capital mobility in addition to Investor Protection, and alternative estimation methods. ${ }^{39}$

Different samples. The results in Table 3 could be sample-specific. I follow Kose et al. (2009) and define a Financially Integrated sample of 47 industrialized and emerging economies whose equities are actively traded in the world capital market (see Table 1 for the list). These are the economies which should be more active in international risk sharing, or they might have a better quality of data. Columns 1-2 of Table 5 show that the main result is preserved: the coefficient of Output Risk is not significant at conventional levels, but the coefficient of the investor protection index is significantly positive in both samples. On an absolute value the effect of investor protection is larger for more open economies than for "less financially integrated" economies, with the value in the Whole World sample in between. ${ }^{40}$ Similar effects are documented by Fratzscher and Imbs (2009) for consumption risk sharing. The positive relationship between income risk sharing and investor protection is not sample-specific. There is suggestive evidence of non-linearity in the response of risk sharing to investor protection depending on the level of equity market integration.

Other potential determinants of risk sharing. In the remainder of Table 5, I report the regressions

\footnotetext{
${ }^{38}$ The estimate of risk sharing $\widehat{\beta}_{i}$ is expressed in percentage points. Given the 2SLS coefficient estimates for Investor Protection in Table 4 the average magnitude effect using the individual point estimates of 2SLS coefficients is 7 percent. From column 3, the magnitude effect of moving from the lowest to the highest quartile in Investor Protection is 8 percentage points $((6.8-5.0) \times 4.43)$.

${ }^{39}$ Investor protection is also conducive to reducing the volatility of income relative to that of output. In a regression, higher values of Investor Protection are associated with lower ratio of the standard deviation of GNI growth to that of GDP growth. The results are available upon request. In a related study, Bekaert et al. (2006) find that countries with better investor protection experience larger decreases in consumption growth volatility after the opening of equity markets to foreign investors.

${ }^{40}$ The significance level of Investor Protection is smaller in sub-samples than in the Whole World sample because there is somewhat less of cross-section variation in the investor protection index.
} 
with other potentially important determinants of risk sharing as additional controls. In column 3, I check whether a positive association between risk sharing and investor protection is due to the fact that only the rich countries share risk internationally (i.e., the level of development affects both the extent of risk sharing and investor protection). The logarithm of the initial level of GDP per capita is insignificant but Investor Protection remains significant. The indicator measures of the extent of legal government restrictions are criticized for failure to account for the effectiveness of capital controls and actual (de facto) country openness to finance (Kose et al., 2006). In column 4, the coefficient of the volume of financial flows relative to GDP is positive but insignificant at conventional levels. ${ }^{41}$ A larger domestic market or a deeper financial market may act as a partial substitute for the international financial market in providing risk sharing opportunities (Beck et al., 2000; Martin and Rey, 2004). In column 5, I add the measures of overall level of domestic credit and equity market development, and in column 6, I control for the size of domestic market (captured by the total GNI). The coefficients of these variables have expected signs but are insignificant. I experiment with proxies of other aspects of domestic institutional quality than investor risk (level of corruption as in column 7, rule or law, and so on)-none of them has a first-order effect on the degree of risk sharing. ${ }^{42}$ The positive relationship between income risk sharing and investor protection is not susceptible to omitted variable bias. ${ }^{43}$

Alternative method to control for outliers. I created the main Whole World sample by dropping some outliers with extreme values of $\widehat{\beta}_{i}$. As an alternative, I employ the least absolute deviation (LAD) regression which puts less weight on outliers than OLS. In the largest sample of 128 countries the LAD coefficient estimates are 1.64 (significant at 2\%) for Investor Protection and 0.43 (insignificant) for Output Risk with pseudo- $R^{2}$ of $2 \%$ (the specification as in column 5 , Table 3 ). Investor Protection has a robust relation with risk sharing despite some possible outliers.

\footnotetext{
${ }^{41}$ This is the main variable of interest investigated by Kose et al. (2006). Trade openness can be complementary to financial integration as in Rajan and Zingales (2003). I also check for the role of volume-based measure of trade openness with similar results.

${ }^{42}$ The institutional quality, broadly defined, is empirically important for the patterns of capital flows (see Wei, 2000; Alfaro et al., 2008). The result is qualitatively similar with the other measures of institutions. In all these experiments the coefficient of institutional quality is positive but insignificant and the coefficient of Investor Protection is significant at least at 5\%. Based on the diagnostic by Belsley (1991) (see footnote 30) multicollinearity is not a major concern in these regressions.

${ }^{43}$ I got the similar result with the proxies for the prudence of macroeconomic policies, tax policy and other domestic fundamentals potentially important for financial integration (human capital, culture, climate, natural resources, and the geographic location). The results are available.
} 


\subsection{Evidence from the panel regression Model 2}

The estimation of the regressor $\widehat{\beta}$ uses relatively few observations. To address possible efficiency concerns I estimate the empirical model in Eq. (7) using panel GLS regression. ${ }^{44}$ I include Output Risk and Investor Protection (demeaned by averages across countries at each year) as interaction and linear terms. I also include the "linear terms" $\left(\mathrm{z}_{i t}-\overline{\mathrm{z}}_{i .}\right)$ into the regression as an additional covariate matrix $X_{i}$ as it is usually done in regressions with interaction effects. The linear term shows whether the variables in $X_{i}$ have a direct effect on the difference in growth rates of GDP and GNI. Table 6 reports the results. Columns 1-2 exclude country-fixed effects and reflect long-run differences between countries with respect to risk sharing. Columns 3-7 include country-fixed effects to account for omitted variables and country heterogeneity in response to year-by-year shocks. Thus, the results there are driven by changes over time and reveal if increasing investor protection goes hand-in-hand with increasing risk sharing. The first line of the table corresponds to the average amount of income risk sharing (in percent) within the group, which is remarkably consistent with the average of the individual-country estimates in Table 2. The interaction term of Investor Protection is positive and highly significant, confirming the results obtained with the cross-section regressions. The positive and significant coefficient of the time trend shows that risk sharing in world capital markets tends to increase over time, which is consistent with Sorensen et al. (2007).

Structural changes over time. There could be a concern that the political regime shifts and market reforms occurring in many developing and ex-Communist countries in the early 1990s could have introduced a 'structural break' in the underlying relationship between the extent of risk sharing and Investor Protection (I thank an anonymous referee for suggesting this check). The empirical evidence on the timing de facto effects of financial market liberalization in developing countries compared to the time when these were implemented (de jure) was provided by, for example, Bekaert et al. (2002). I observe the evidence of such reforms as an increase of the cross-sectional average of the Investor Protection index over time (available upon request). Then, if there is a break in the underlying factors conducive to risk sharing, we would expect to see an increase in the estimated extent risk sharing over time, especially after the reforms took place (the break period). The most

\footnotetext{
${ }^{44}$ The estimation involves two stages and assumes that the error variance differs across countries. In the first stage, I estimate the model by the OLS and obtain the standard deviations of the residuals for each country. In the second stage, I weigh each country with the inverse of its standard deviation and re-estimate the model. I also correct for possible autocorrelation in residuals assuming that the error term in each country is AR(1).
} 
efficient way to deal with this issue is to employ Markov switching methodologies or to determine endogenous break dates by the method in Bekaert et al. Unfortunately, a relatively short the timeseries dimension of my data (20 years, at best) does not make it feasible to estimate endogenous break point by these methods. Nevertheless, I try to provide the suggestive evidence of the existence and the nature of such breaks in my data in the reminder of the table. In Column 5, I introduce the interaction with Post-Transition (1995) Period binary variable, instead of interaction with time trend. The new variable takes the value of 1 from 1995 (the year of postulated brake)-onward, and zero otherwise. The coefficient of the interaction dummy is positively and highly significant, indicating the existence of the positive, as expected, structural break in the extent of income risk sharing in the period characterized by increased capital market integration/liberalization and the effect of reforms. ${ }^{45}$ The coefficient capturing the average extent of risk sharing loses significance. This is not surprising, since its effect is taken over by the dummy, but the coefficient of the Investor Protection remains positive and highly significant. Finally, I split the time period 1985-2004 in half into before and after 1995, and estimate the model with time trend and time and country fixed effects. As seen in Columns 6 and 7, the more recent period witnesses much larger extent of average risk sharing ( $4.7 \%$ vs. $0.6 \%)$. In addition, there is a change toward a positive trend in risk sharing in the later period as indicated by the coefficient of the Time Trend interaction. Investor Protection is robustly significant and positive throughout, but the importance of this factor increases over time (the coefficient grows in absolute value) for income risk sharing, as should be the case in the period when foreign capital becomes more important.

Consumption risk sharing. Appendix B provides suggestive evidence for the total consumption risk sharing using country data for final consumption expenditure. Subject to the qualification as to the quality of international consumption data, domestic investor protection is positively correlated with the measure of overall risk sharing. While I do not interpret the estimated relationship as

\footnotetext{
${ }^{45}$ Since the "true" date of the break is unknown I try various years: the 1995 , since after this year most of the countries in Eastern Europe were done with privatization programs, those with hyperinflation in early 1990s (mostly the former USSR and Eastern Europe, but also Peru and Nicaragua) finally stabilized the prices, and we see an improvement in overall investor protection about from about this time; the 1998, as the year past 1997 East Asian Crisis and and of the Russian Crisis; the 2000, when most of the effects of the above crises must have been overcome, and many of emerging markets turned to the positive economic growth; the 1991, as the very beginning of the period after the fall of Communism and also the end of the "lost decade" (the 1980s) in Latin America. The coefficient of the dummy increases at the absolute value as we define the break later, which is consistent with the evidence of the upward trend in the degree of risk sharing documented in the original draft, and by a recent literature on risk sharing. The time of the break is clearly the mid-1990s; when I define the date of break in 1991 it is not significant. The results for the other break dates are available upon request.
} 
causal, the size of the coefficients implies a much smaller, although non-trivial, economic effect of investor protection on total risk sharing compared to the effect on international income risk sharing. Moreover, there is a change toward a positive trend in risk sharing in the later period, as indicated by the coefficient of the Time Trend interaction, and a more recent period witnesses much larger extent of average consumption risk sharing. More research is needed to determine how the institutional quality affects each channel of risk sharing.

\section{Conclusion}

Better insurance of consumption against country-specific output risk is an important benefit of international financial integration. I explore a channel of risk sharing associated with international asset diversification and investment income flows. Empirically, countries with lower investor protection scores generally obtain lower risk sharing in the world capital market. This result withstands a number of robustness checks. The recent experience of two former socialist economies in Eastern Europe, Poland and Hungary, provides a case in point. According to my estimates, Poland smoothed 13 percent of idiosyncratic shocks to GDP by net factor income flows from abroad whereas Hungary smoothed virtually none (see Table 1). The two countries are similar in regards to geography, economic policies, inefficiency of judiciary, and socio-economic indicators, except for the corporate disclosure and the stock market regulation. In the early 1990s Poland introduced a tough securities law focused on reducing the practice of massive expropriation of minority shareholders (the so-called "tunneling" of assets). Hungary's corporate laws still grant significant powers to large investors. ${ }^{46}$ Poland's focus on investor protection seemed to play a beneficial role despite a somewhat larger volume of gross capital flows in Hungary.

This paper can be extended in several ways. First, it would be interesting to disentangle the direct effect of cross-border frictions on income risk sharing working through the asset composition of country portfolios and the indirect effect through the volume of international income flows. Second, I find suggestive evidence of the positive association of domestic investor protection and

\footnotetext{
${ }^{46}$ Under the new Polish law any group with 5 percent of the company can demand an independent audit and each share in a public company may carry only one vote at a general shareholder meeting. In Hungary shareholders must command 10 percent of a company's votes to demand an audit or meeting, and some shares can carry as high as ten votes. See Economist (2001). The value of the index of minority investor protection I use in this paper is 6.0 for Poland and just 4.3 for Hungary indicating much better minority shareholder protection in Poland.
} 
overall consumption risk sharing. It is necessary to establish the contribution of investor protection to other channels of risk sharing (through saving, government and private transfers, and so on) in order to better understand its effect on the overall consumption risk sharing. Third, the response of income risk sharing to investor protection seems to be non-linear, depending on the level of equity market integration. While in this paper I focus mainly on direct effect of investor rights on risk sharing, it is important to understand the "collateral benefits" of financial integration. It is quite possible that integration would promote development of the domestic financial sector, and improve institutions and macroeconomic policies. These advances could facilitate risk sharing through other channels, not covered in this paper. ${ }^{47}$ I find a suggestive evidence of a structural break in the underlying relations behind the extent of risk sharing over time, where the more recent years, specifically post-1995, see an increased extent of income or total consumption risk sharing and the correlation of Investor Protection with the extent of risk sharing becomes stronger over time. Uncovering the determinants of these channels would help formulate adequate policy steps.

\footnotetext{
${ }^{47}$ For a preliminary evidence for the positive effect of financial openness on other channels or risk sharing see Sorensen et al. (2007), Fratzscher and Imbs (2009), and Kose et al. (2009) who find positive effects of openness on overall consumption risk sharing. Fratzscher and Imbs also document non-linearity effects.
} 


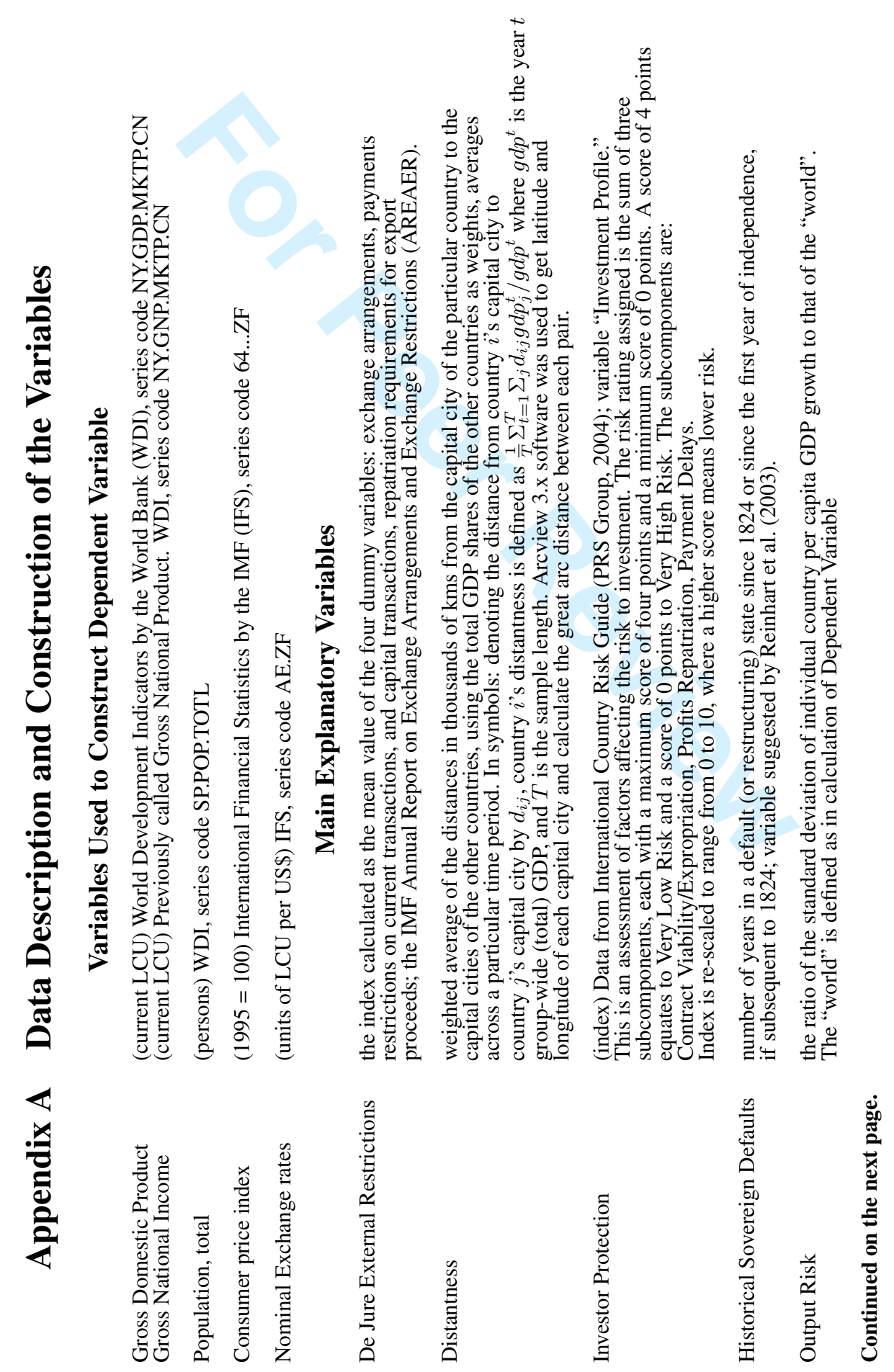

Editorial Office, Dept of Economics, Warwick University, Coventry CV4 7AL, UK 


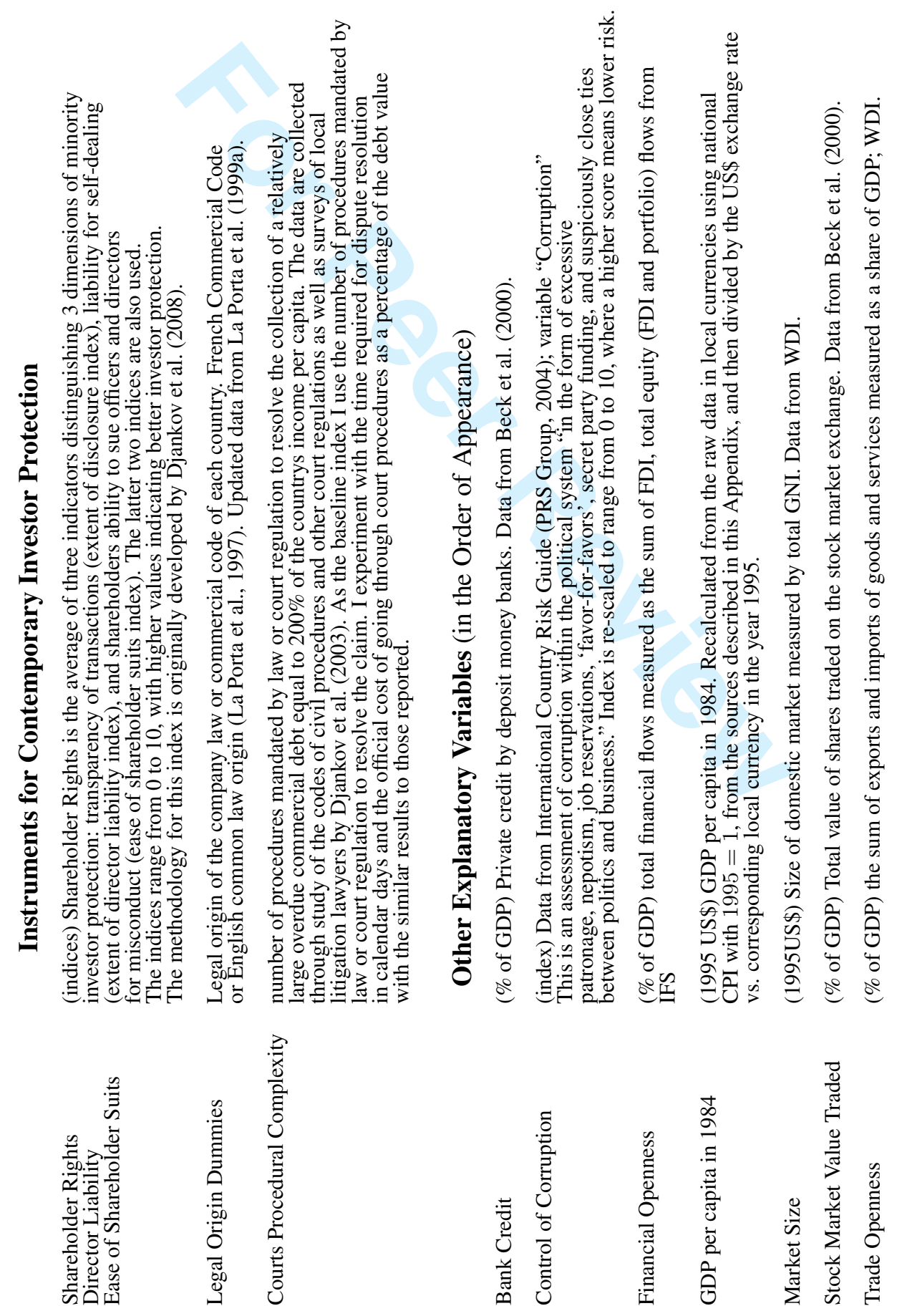

Editorial Office, Dept of Economics, Warwick University, Coventry CV4 7AL, UK 


\section{Appendix B Evidence on consumption risk sharing}

This Appendix provides suggestive evidence for the overall consumption risk sharing. The empirical issues involve a complex chain of events between the shock to output and realization of consumption, aggravated by data issues (see Obstfeld, $1994 \mathrm{~b}$ for the early data quality warnings). ${ }^{48}$ Stockman and Tesar (1995) demonstrate that a model with full risk sharing can generate high consumption volatility and be interpreted as lack of risk sharing when countries are subject to idiosyncratic "taste shocks" of a reasonable magnitude. ${ }^{49}$ A large literature on private consumption and saving behavior surveyed by Loayza et al. (2000) documents a number empirical puzzles and policy questions. Recently Deaton and Heston outline a number of theoretical and practical issues with commonly used international datasets (Penn World Table, World Bank's World Development Indicators) that are especially detrimental for the work with cross-country consumption data (see Deaton and Heston, 2010).

As discussed by Sorensen and Yosha (1998), consumption risk sharing could be obtained through cross-ownership of productive assets, intertemporal borrowing and lending internationally or in domestic markets, and by central fiscal institutions. It is impossible to estimate the incremental percentage of shocks to GDP absorbed through each of these channels because the necessary data (gross national income, net national income, net national disposable income) is absent for most, except for a few, economies. I use available data for final consumption expenditure (formerly total consumption) from the World Bank (WDI code NE.CON.TOTL.CN), which is the sum of household final consumption expenditure (private consumption) and general government final consumption expenditure, expressed in per capita 1995 U.S. dollars and calculate growth rates as yearly log-differences.

Table 7 reports the results of the GLS estimation of the empirical model in Eq. (7) using consumption data instead of GNI data. The average amount of consumption risk sharing in the largest sample (the first line in the table) is $23-27$ percent-much larger than the average international income risk sharing reported in Table 6. This result is not surprising given the findings of a number of papers on the dominant role of saving channel. Consistent with this literature, most notably

\footnotetext{
${ }^{48}$ Carroll et al. (2008) discuss the estimation issues (such as measurement error and time aggregation) in aggregate consumption data in detail. Rogoff (2007) points on quite different aggregate volatility pattern depending on whether yearly or quarterly data are used.

${ }^{49}$ Stockman and Tesar refer to the multiplicative disturbances to individual utility function as "taste shocks." They interpret taste shocks very broadly to include consumer sentiment, policy shocks, and so on.
} 
Balli and Sorensen (2007) for the EU, I do not find any significant trend in the total risk sharing. I speculate that the negative coefficient of the interaction term of Output Risk could imply the effect of government pro-cyclical saving (also documented by Balli and Sorensen, 2007) in more volatile economies. However, Column 5 points to an evidence of an exogenous break in the underlying relationship between the extent of total risk sharing. The results (not reported for brevity but available upon request) are quite nuanced for total consumption risk sharing. They indicate the possibility of several breaks over the course of the 1990s: there is a reduction in the extent of risk sharing if we define the break in 1991, and this effect reverses only in late 1990s. Splitting the sample into half we see in Column 6 and 7 that the more recent period witnesses much larger extent of average consumption risk sharing (37\% vs. $32 \%)$. In addition, there is a change toward a positive trend in consumption risk sharing in the later period as indicated by the coefficient of the Time Trend interaction. Investor Protection is robustly significant and positive throughout.

To sum up, subject to the qualification as to the quality of international consumption data, domestic investor protection is positively correlated with the measure of overall risk sharing. If the relationship in Table 7 were causal, the magnitude of the coefficient of this interaction term would imply a much smaller, although non-trivial, economic effect of investor protection on total risk sharing compared to the effect on international income risk sharing. More research is needed to determine how the institutional quality affects each channel of risk sharing. 


\section{References}

Acemoglu, D., Zilibotti, F., 1997. Was Prometheus Unbound by Chance? Risk, Diversification, and Growth. Journal of Political Economy 105, 709-751.

Alfaro, L., Kalemli-Ozcan, S., Volosovych, V., 2008. Why Doesn't Capital Flow from Rich to Poor Countries? An Empirical Investigation. Review of Economics and Statistics 90, 347-368.

Artis, M. J., Hoffmann, M., 2008. Declining Home Bias and the Increase in International Risk Sharing: Lessons from European Integration. In: Jonung, L., Walkner, C., Watson, M. (Eds.), Building the Financial Foundations of the Euro: Experiences and Challenges. Routledge.

Asdrubali, P., Sorensen, B., Yosha, O., 1996. Channels of Interstate Risk Sharing: United States 1963-90. Quarterly Journal of Economics 111, 1081-1110.

Asdrubali, P., Kim, S., 2008. On the empirics of international smoothing. Journal of Banking and Finance 32, 374-381.

Backus, D., Kehoe, P., Kydland, F., 1992. International Real Business Cycles. Journal of Political Economy 100, 745-775.

Balli, F., Sorensen, B., 2007. Risk Sharing among OECD and EU Countries: The Role of Capital Gains, Capital Income, Transfers, and Saving, MPRA Paper 10223, University Library of Munich, Germany.

Baxter, M., Crucini, M., 1995. Business Cycles and the Asset Structure of Foreign Trade. International Economic Review 36, 821-854.

Beck, T., Demirguc-Kunt, A., Levine, R., 2000. A New Database on Financial Development and Structure. World Bank Economic Review 14, 597-605.

Becker, S. O., Hoffmann, M., 2006. Intra- and international risk-sharing in the short run and the long run. European Economic Review 50, 777-806.

Bekaert, G., Harvey, C.R., Lumsdaine, R.L., 2002. Dating the Integration of World Equity Markets. Journal of Financial Economics 65, 203-247.

Bekaert, G., Harvey, C.R., Lundblad, C.T., 2006. Growth volatility and equity market liberalization. Journal of International Money and Finance 25, 370-403.

Belsley, D.A., 1991. Conditioning Diagnostics, Collinearity and Weak Data in Regression. John Wiley \& Sons, New York.

Borensztein, E.R., Mauro, P., 2004. The Case for GDP-Indexed Bonds. Economic Policy 19, 165-216.

Broner, F.A., Ventura, J., 2010. Rethinking the Effects of Financial Liberalization. CEPR Discussion Paper DP8171. Available at SSRN: http://ssrn.com/abstract=1742696

Canova, F., Ravn, M., 1996. International Consumption Risk Sharing. International Economic Review 37, 573-601.

Campbell, J. Y., Mankiw, N. G., 1989. Consumption, Income and Interest Rates: Reinterpreting the Time Series Evidence. In: Blanchard, O. J., Fischer, S. (Eds.), NBER Macroeconomics Annual 1989. MIT Press, Cambridge, MA.

Carroll, C. D., Slacalek, J., Sommer, M., 2008. International Evidence on Sticky Consumption Growth. NBER Working Paper No. 13876, March.

Castro, R., Clementi, G.L., MacDonald, G., 2004. Investor Protection, Optimal Incentives, and Economic Growth. Quarterly Journal of Economics 119, 1131-1175.

Claessens, S., Klingebiel, D., Schmukler, S., 2006. Stock Market Development and Internationalization: Do Economic Fundamentals Spur both Similarly? Journal of Empirical Finance 13, 316-350.

Claessens, S., Schmukler, S., 2007. International Financial Integration Through Equity Markets: Which Firms from which Countries Go Global? Journal of International Money and Finance 26, 788-813. 
Crucini, M., 1999. On International and National Dimensions of Risk Sharing. Review of Economics and Statistics 81, 73-84.

Deaton, A., Heston, A., 2010. Understanding PPPs and PPP-based national accounts. American Economic Journal: Macroeconomics 2, 1-35.

Demyanyk, Y., Ostergaard, C., Sorensen, B., 2007. U.S. banking deregulation, small businesses, and interstate insurance of personal income. Journal of Finance 62, 2763-2801.

Djankov, S., La Porta, R., Lopez-de-Silanes, R., Shleifer, A., 2003. Courts. Quarterly Journal of Economics $118,453-517$.

Djankov, S., La Porta, R., Lopez-de-Silanes, R., Shleifer, A., 2008. The law and economics of self-dealing. Journal of Financial Economics 88. 430-465.

Doidge, C., Karolyi, G., Stulz, R., 2004. Why are foreign firms listed in the U.S. worth more? Journal of Financial Economics 71, 205-238.

The Economist. 2001. Like Uncle Sam. March 8th. From The Economist print edition. Available at http://www.economist.com/displayStory.cfm?story_id=526638

Forni, M., Reichlin L., 1999. Risk and potential insurance in Europe. European Economic Review 43, 1237 1256.

Frankel, J., Romer, D., 1999. Does Trade Cause Growth? American Economic Review 89, 379-399.

Fratzscher, M., Imbs, J., 2009. Risk sharing, finance and institutions in international portfolios. Journal of Financial Economics 94, 428-447.

Gerry, C.J., Li, C.A., 2010. Consumption smoothing and vulnerability in Russia. Applied Economics 42, 1995-2007.

Gertler, M., Rogoff, K., 1990. North-South Lending and Endogeneous Domestic Capital Market Ineffciencies. Journal of Monetary Economics 26, 245-266.

Glaeser, E.L., Shleifer, A., 2002. Legal Origins. Quarterly Journal of Economics 117, 1193-1229.

Gordon, R.H., Bovenberg, A.L., 1996. Why is Capital so Immobile Internationally? Possible Explanations and Implications for Capital Income Taxation? American Economic Review 86, 1057-1075.

Gourinchas, P.-O., Jeanne, O, 2006. The elusive gains from international financial integration. Review of Economic Studies 73, 715-741.

Heathcote J., Perri, F., 2004. Financial Globalization and Real Regionalization. Journal of Economic Theory $119,207-243$.

Heathcote J., Perri, F., 2008. The International Diversification Puzzle is not as Bad as You Think. CEPR Discussion Paper 6982.

Helpman, E., Razin, A., 1978. A Theory of International Trade Under Uncertainty. Academic Press, New York.

Imbs, J., 2004. Trade, Finance, Specialization, and Synchronization. Review of Economics and Statistics 86, 723-734.

International Monetary Fund, 2005a. Globalization and External Imbalances. World Economic Outlook. April 2005. International Monetary Fund, Washington, DC.

Jalan, J., Ravallion, M., 1999. Are the poor less well insured? Evidence on vulnerability to income risk in rural China. Journal of Development Economics 58, 61-81.

Kalemli-Ozcan, S., Sorensen, B., Yosha, O., 2003. Risk sharing and industrial specialization: regional and international evidence. American Economic Review 93, 903-918.

Karolyi, G. A., 2004. The Role of American Depositary Receipts in the Development of Emerging Equity Markets. Review of Economics and Statistics 86, 670-690. 
Kose, A.M., Prasad, E., Terrones, M.E., 2009. Does Financial Globalization Promote Risk Sharing? Journal of Development Economics 89, 258-270.

Kose, A.M., Prasad, E., Rogoff, K., Wei, S.-J., 2006. Financial Globalization: A Reappraisal. IMF Working Paper WP/06/189. International Monetary Fund, Washington, DC.

La Porta, Rafael, Lopez-de-Silanes, F., Shleifer, A, Vishny, R., 1997. Legal Determinants of External Finance. Journal of Finance 52, 1131-1150.

La Porta, R., Lopez-de-Silanes, F., Shleifer, A, Vishny, R., 1998. Law and Finance. Journal of Political Economy 106, 1113-1155.

La Porta, R., Lopez-de-Silanes, F., Shleifer, A, Vishny, R., 1999a. The Quality of Government. Journal of Law, Economics and Organization 15, 222-279.

Leibrecht, M., Scharler, J., 2011. Borrowing constraints and international risk sharing: evidence from asymmetric error-correction. Applied Economics 43, 2177-2184.

Loayza, N., Schmidt-Hebbel, K., Serven, L., 2000. Saving in developing countries: An overview. The World Bank Economic Review 14, 392-605

Lewis, K., 1996. What can explain the apparent lack of international consumption risk sharing? Journal of Political Economy 104, 267-297.

Lewis, K., 1999. Trying to explain home bias in equities and consumption. Journal of Economic Literature 37, 571-608.

Martin, P., Rey, H., 2004. Financial Super-Markets: Size Matters for Asset Trade. Journal of International Economics 64, 335-361.

Melitz, J., Zumer, F. 1999, Interregional and International Risk Sharing and Lessons for EMU. CarnegieRochester Conference Series on Public Policy 51, 149-188.

Obstfeld, M., 1994a. Risk-Taking, Global Diversification, and Growth. American Economic Review 84, $1310-1329$.

Obstfeld, M., 1994b. Are Industrial-Country Consumption Risks Globally Diversified? in: Leiderman, L., Razin, A. (Eds.), Capital Mobility: The Impact on Consumption, Investment and Growth. Cambridge University Press, New York.

Obstfeld, M., Rogoff, K., 1996. Foundations of International Macroeconomics. MIT Press, Cambridge, MA.

Obstfeld, M., Rogoff, K., 2000. The Six Major Puzzles in International Macroeconomics: Is There a Common Cause? in: Bernanke, B.S., Rogoff, K. (Eds.), NBER Macroeconomic Annual 2000. MIT Press, Cambridge, MA.

Obstfeld, M., Taylor, A.M., 2004. Global Capital Markets: Integration, Crisis, and Growth. Cambridge University Press, New York.

Portes, R., Rey, H., 2005. The Determinants of Cross Border Equity Flows. Journal of International Economics 65, 269-296.

The PRS Group, 2004. The International Country Risk Guide. The PRS Group, Inc., East Syracuse, NY

Rajan, R.G., Zingales, L., 2003. The Great Reversals: The Politics of Financial Development in the 20th Century. Journal of Financial Economics 69, 5-50.

Ravallion, M., Chaudhuri, S., 1997. Risk and insurance in village India: comment. Econometrica 65, 171184.

Reinhart, C.M., Rogoff, K.S., 2004. Serial Default and the "Paradox" of Rich-to-Poor Capital Flows. American Economic Review 94, 53-59.

Reinhart, C.M., Rogoff, K.S., Savastano, M.A., 2003. Debt Intolerance. Brookings Papers on Economic Activity 1, 1-74. 
Rogoff, K., 2007. Impact of Globalization on Monetary Policy. In: Federal Reserve Bank of Kansas City, The New Economic Geography: Effects and Policy Implications. Kansas City Federal Reserve "Jackson Hole" conference held in August 2006.

Rogoff, K., 2011. Global Imbalances without Tears. The Project Syndicate. www.projectsyndicate.org/commentary/rogoff78/English, accessed on 21 Aug. 2011.

Schmukler, S., Vesperoni, E., 2006. Financial globalization and debt maturity in emerging economies. Journal of Development Economics 79, 183-207.

Sorensen, B., Yosha, O., 1998. International Risk Sharing and European Monetary Unification. Journal of International Economics 45, 211-238.

Sorensen, B., Wu, Y.-T., Yosha, O., Zhu., Y., 2007. Home Bias and International Risk Sharing. Twin Puzzles Separated at Birth. Journal of International Money and Finance 26, 587-605.

Stockman, A., Tesar, L., 1995. Tastes and technology in a two-country model of the business cycle: Explaining international comovements. American Economic Review 85, 168-185.

Stulz, R., 2005. The Limits of Financial Globalization, Journal of Finance 60, 1595-1637.

Tesar, L., 1995. Evaluating the Gains from International Risk Sharing. Carnegie-Rochester Conference Series on Public Policy 42, 95-143.

Tirole, J., 2002. Financial Crises, Liquidity, and the International Monetary System. Princeton University Press, Princeton, NJ.

Van Wincoop, E., 1994. Welfare Gains from International Risk Sharing. Journal of Monetary Economics 34, 175-200.

Wei, S.-J., 2000. How taxing is corruption on international investors? Review of Economics and Statistics $82,1-11$

United Nations, 2005. System of National Accounts 1993. Updated and Revised. Available at unstats.un.org/unsd/sna1993/. Accessed in July 2008. 
Whole World sample (117 countries): all countries with data available for GDP per capita and Investor Protection . Countries with missing data for a particular set of explanatory variables are dropped as described in notes to corresponding regression tables. The countries included (with abbreviated names in brackets) are listed below.

Financially Integrated sample (47 countries, in bold): industrialized and "more financially integrated" emerging economies as defined by Morgan Stanley Capital International Inc. (MSCI). MSCI defines broad market representation by securities international institutional investors can gain exposure to in a given market. A target of $85 \%$ of free float-adjusted market representation within each industry group, within each country is used as a guideline. MSCI covers 23 developed and 27 emerging market country indices.

\begin{tabular}{|c|c|c|c|c|c|}
\hline Algeria & 4.29 & Ghana & -0.57 & Norway & -2.70 \\
\hline Angola & 18.53 & Greece & 5.27 & Oman & -6.99 \\
\hline Argentina & 3.09 & Guatemala & -1.96 & Pakistan & 0.41 \\
\hline Armenia & 26.86 & Guinea Bissau & -0.91 & Panama & 10.65 \\
\hline Australia & 1.94 & Guyana & -4.85 & Paraguay & -0.11 \\
\hline Austria & 14.74 & Haiti & 2.15 & Peru & -7.23 \\
\hline Azerbaijan & 3.42 & Honduras & -13.93 & Philippines & 2.06 \\
\hline Bahamas & 0.62 & Hong Kong & -2.08 & Poland & 13.09 \\
\hline Bahrain & -10.62 & Hungary & -0.70 & Portugal & -12.98 \\
\hline Belarus & -0.18 & Iceland & 3.12 & Qatar & 8.12 \\
\hline Belgium & 12.76 & India & -2.55 & Romania & -1.00 \\
\hline Bolivia & 1.26 & Indonesia & -3.63 & Russia & -9.33 \\
\hline Botswana & 10.82 & Iran & -17.16 & Saudi Arabia & 8.99 \\
\hline Brazil & 2.07 & Ireland & 19.65 & Senegal & -0.78 \\
\hline Bulgaria & 4.27 & Israel & 2.01 & Singapore & 3.46 \\
\hline Cameroon & 9.60 & Italy & 11.19 & Slovak Rep. & -3.11 \\
\hline Canada & 11.87 & Jamaica & -4.92 & Slovenia & 7.54 \\
\hline Chile & 0.18 & Japan & -1.26 & South Africa & 13.60 \\
\hline China & 1.34 & Jordan & -12.36 & Spain & 3.31 \\
\hline Colombia & -5.11 & Kazakhstan & 2.00 & Sri Lanka & -2.39 \\
\hline Congo Dem.Rep. & -7.74 & Kenya & -10.02 & Sudan & -12.85 \\
\hline Congo Rep. & 5.06 & Korea Rep. & -5.93 & Sweden & 6.80 \\
\hline Costa Rica & 13.66 & Kuwait & 25.69 & Syria & -6.05 \\
\hline Cote d'Ivoire & 13.13 & Latvia & 5.80 & Tanzania & 0.05 \\
\hline Croatia & 0.18 & Lithuania & 3.72 & Thailand & -4.94 \\
\hline Cyprus & 0.61 & Madagascar & -3.31 & Togo & 4.72 \\
\hline Czech Rep. & 31.41 & Malawi & -4.33 & Trinidad and Tobago & -2.41 \\
\hline Denmark & 14.48 & Malaysia & 1.64 & Tunisia & 0.62 \\
\hline Dominican Rep. & 4.82 & Mali & 8.05 & Turkey & -10.95 \\
\hline Ecuador & -4.41 & Malta & -12.40 & Uganda & -2.50 \\
\hline Egypt & -18.02 & Mexico & -5.34 & Ukraine & -2.11 \\
\hline El Salvador & 0.56 & Moldova & -2.43 & United Kingdom & -7.13 \\
\hline Estonia & 28.89 & Mongolia & -4.49 & United States & 3.06 \\
\hline Ethiopia & -4.87 & Morocco & -2.88 & Uruguay & 1.00 \\
\hline Finland & -12.01 & Mozambique & 15.69 & Venezuela & -4.96 \\
\hline France & 3.47 & Myanmar & 0.04 & Vietnam & 5.83 \\
\hline Gabon & 2.52 & Netherlands & 5.63 & Yemen & -5.98 \\
\hline Gambia & 28.85 & New Zealand & 0.67 & Zambia & 11.99 \\
\hline Germany & -0.71 & Niger & 18.76 & Zimbabwe & -2.03 \\
\hline
\end{tabular}

Notes: The individual country's percentage of the idiosyncratic risk to GDP smoothed through factor income flows (the extent of income insurance, $\widehat{\beta}_{i}$ ) estimated as described in Section 3. 
Table 2: Descriptive Statistics and Correlation Coefficients for the Main Variables. Whole World. 1985-2004

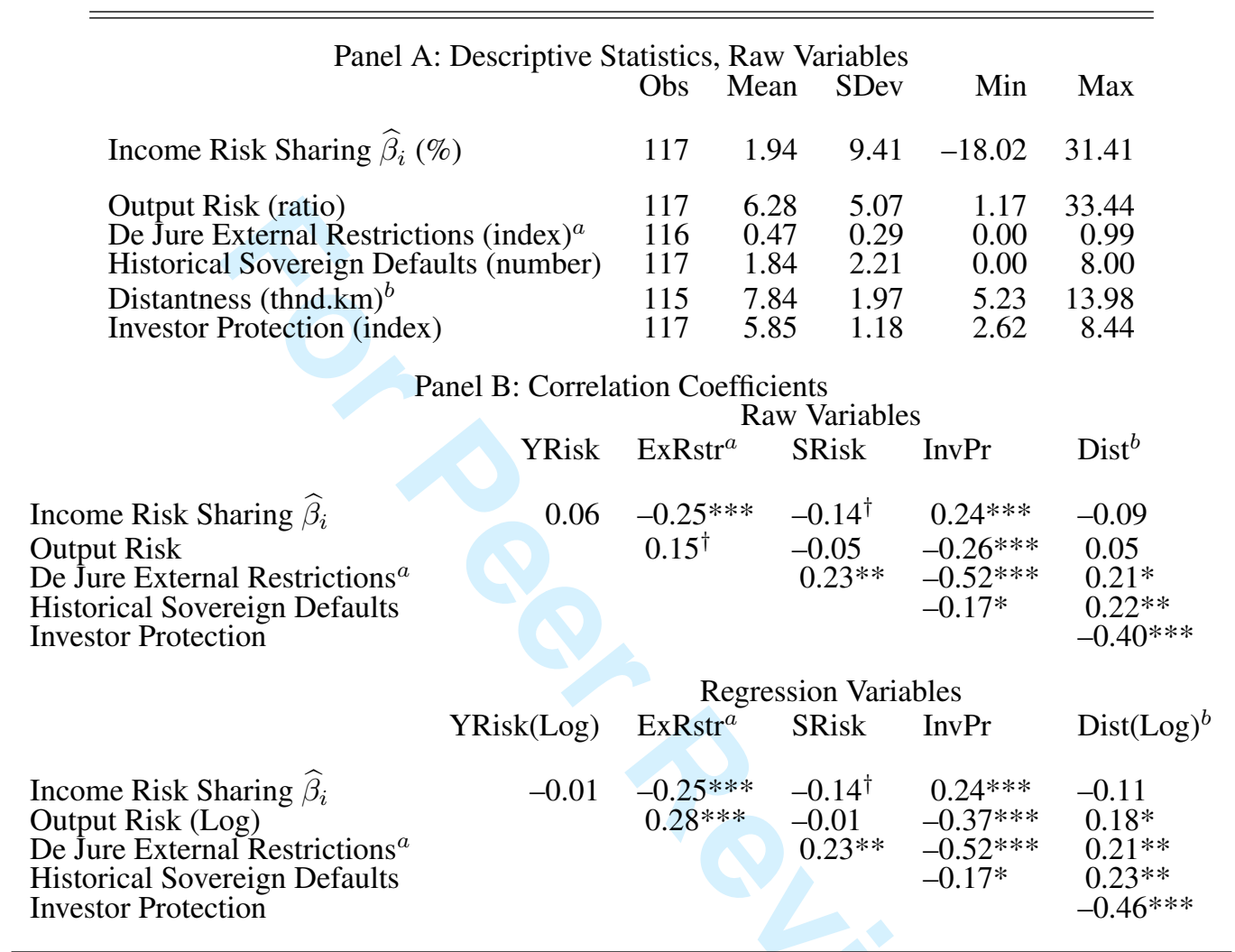

Notes: All variables in Panel A are in original units; the way they are transformed in regression analysis is described in corresponding notes to the following regression tables. All variables are sample averages. Income Risk Sharing $\left(\widehat{\beta}_{i}\right)$ is the estimates of the percentage of the idiosyncratic risk to income smoothed through factor income flows. It is estimated as described in Section 3. Panel B reports the correlations of the variables in the original units and in the form they come into the regressions. In this Table $\beta_{i}$ represents estimate of Income Risk Sharing; YRisk—Output Risk ; ExRstr-De Jure External Restrictions; InvPr—Investor Protection (ICRG); SRisk—Historical Sovereign Defaults; Dist—Distantness. All the variables are sample averages. See Appendix Appendix A for detailed description of the variables. ***, **,*, and ${ }^{\dagger}$ denote significance at $1 \%, 5 \%, 10 \%$, and $15 \%$.

Samples: The Whole World sample (117 countries) includes all countries with data available for GDP per capita and Institutional Quality. Countries with missing data for a particular set of explanatory variables are dropped as described henceforth. See Appendix Appendix A for detailed description of the variables. ${ }^{a}$ Limited 116-country sample due to missing data on De Jure External Restrictions for AGO. ${ }^{b}$ Limited 115 -country sample due to missing data on Distantness for DZA, MNG. Notice that because of missing data for AGO, DZA, MNG the samples including De Jure External Restrictions and Distantness have correspondingly less than 117 observations (minimum is 114). 
Table 3: OLS Regressions. Explaining Income Risk Sharing. Measures of Barriers to Capital Mobility. Whole World. 1985-2004

\begin{tabular}{|c|c|c|c|c|c|c|}
\hline & $(1)$ & $(2)$ & (3) & (4) & $(5)$ & (6) \\
\hline \multicolumn{7}{|c|}{ Dependent Var.: Estimate of Income Risk Sharing, $\widehat{\beta}_{i}$} \\
\hline $\begin{array}{l}\text { Output } \\
\text { Risk (Log) }\end{array}$ & $\begin{array}{l}-0.18 \\
(1.22)\end{array}$ & $\begin{array}{c}0.16 \\
(1.17)\end{array}$ & $\begin{array}{l}-0.19 \\
(1.20)\end{array}$ & $\begin{array}{c}0.08 \\
(1.19)\end{array}$ & $\begin{array}{c}1.16 \\
(1.21)\end{array}$ & $\begin{array}{c}0.67 \\
(1.13)\end{array}$ \\
\hline $\begin{array}{l}\text { De Jure External } \\
\text { Restrictions }\end{array}$ & & $\begin{array}{c}-8.14 * * * \\
(3.11)\end{array}$ & & & & $\begin{array}{l}-4.90^{\dagger} \\
(3.35)\end{array}$ \\
\hline $\begin{array}{l}\text { Historical } \\
\text { Sovereign Defaults }\end{array}$ & & & $\begin{array}{l}-0.60 * \\
(0.31)\end{array}$ & & & $\begin{array}{l}-0.30 \\
(0.30)\end{array}$ \\
\hline $\begin{array}{l}\text { Distantness } \\
\text { (Log) }\end{array}$ & & & & $\begin{array}{l}-4.25 \\
(3.18)\end{array}$ & & $\begin{array}{l}-0.01 \\
(3.13)\end{array}$ \\
\hline $\begin{array}{l}\text { Investor } \\
\text { Protection }\end{array}$ & & & & & $\begin{array}{c}2.18 * * * \\
(0.72)\end{array}$ & $\begin{array}{l}1.49^{*} \\
(0.79)\end{array}$ \\
\hline$R^{2}$ & 0.00 & 0.06 & 0.02 & 0.01 & 0.06 & 0.09 \\
\hline Observations & 117 & $116^{a}$ & 117 & $115^{b}$ & 117 & $114^{c}$ \\
\hline
\end{tabular}

Notes: Dependent variable is the individual country's percentage of the idiosyncratic risk to GDP smoothed through factor income flows (the extent of income insurance, $\beta_{i}$ ) estimated as described in Section 3. All regressions include a constant and are estimated by OLS with White's correction of heteroskedasticity. Standard errors are in parentheses. *** , **, $*$, and ${ }^{\dagger}$ denote significance at $1 \%, 5 \%, 10 \%$, and $15 \%$ under null that the coefficient is zero. All the variables are sample averages. See Appendix Appendix A for detailed description of the variables and Table 2 for descriptive statistics. Samples: The Whole World sample (117 countries) includes all countries with data available for GDP per capita and Institutional Quality. Countries with missing data for a particular set of explanatory variables are dropped as described henceforth. ${ }^{a}$ Limited 116-country sample due to missing data on De Jure External Restrictions for AGO. ${ }^{b}$ Limited 115 country sample due to missing data on Distantness for DZA, MNG. ${ }^{c}$ Limited 114-country sample due to missing data for AGO, DZA, MNG. 
Table 4: IV Regressions. Explaining Income Risk Sharing. Historical Institutions. Whole World. 1985-2004

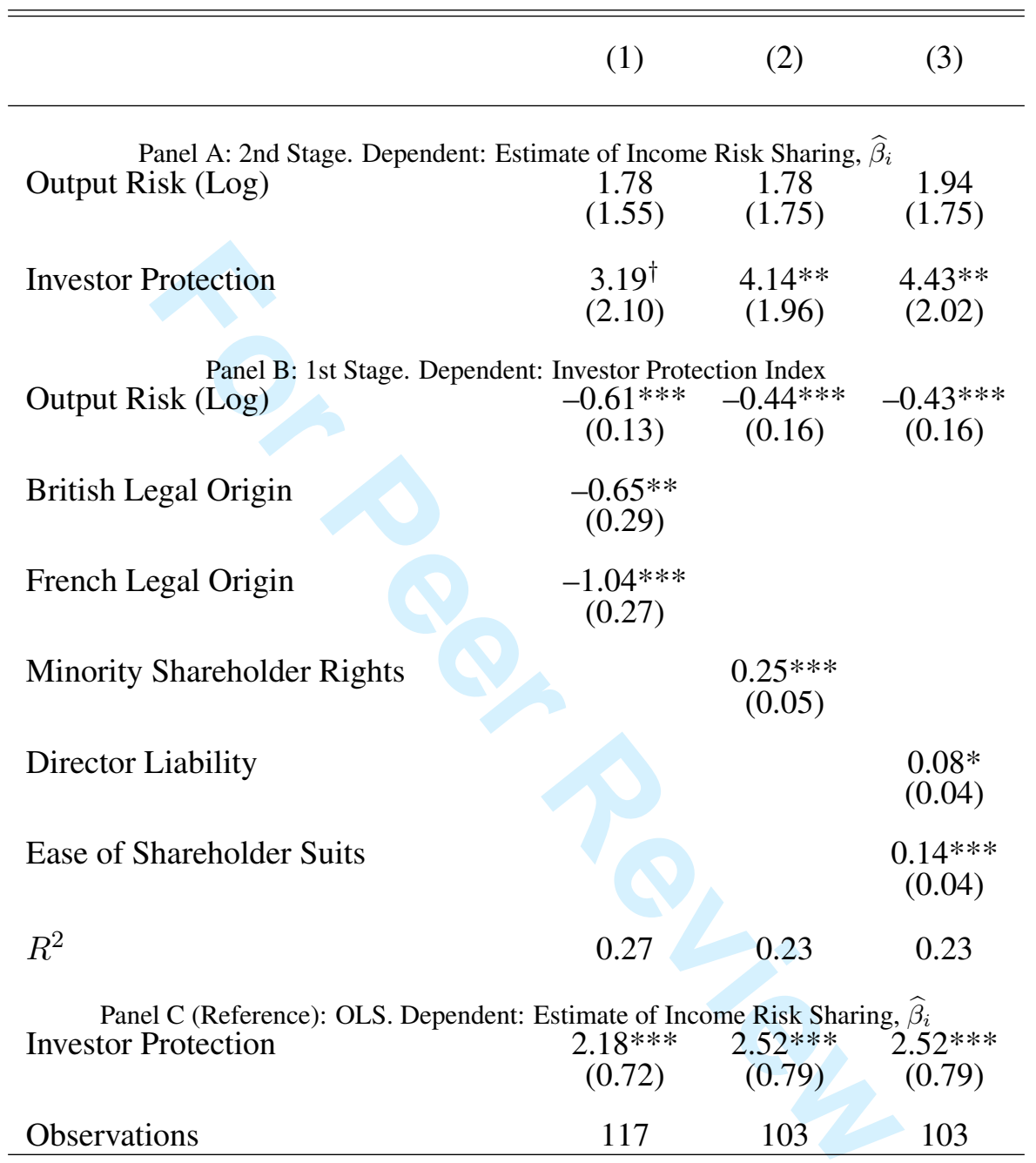

Notes: In Panel A and $\mathrm{C}$ dependent variable is the individual country's percentage of the idiosyncratic risk to GDP smoothed through factor income flows (the extent of income insurance, $\beta_{i}$ ) estimated as described in Section 3. Panel $\mathrm{C}$ reports the OLS coefficient of only Investor Protection from regressing $\beta_{i}$ on the Investor Protection index and Output Risk. All regressions include a constant and are estimated by OLS with White's correction of heteroskedasticity. Standard errors are in parentheses. $* * *, * *, *$, and ${ }^{\dagger}$ denote significance at $1 \%, 5 \%, 10 \%$, and $15 \%$ under null that the coefficient is zero. All the variables are sample averages. See Appendix Appendix A for detailed description of the variables and Table 2 for descriptive statistics. Samples: The Whole World sample includes all countries with data available for GDP per capita and the other controls in a particular specification. 
Table 5: OLS Regressions. Explaining Income Risk Sharing. Robustness Checks: Different Samples and Other Controls. 1985-2004

\begin{tabular}{|c|c|c|c|c|c|c|c|}
\hline & $\begin{array}{l}(1) \\
\text { Financially } \\
\text { Integrated }\end{array}$ & $\begin{array}{c}(2) \\
\text { Less } \\
\text { Integrated }\end{array}$ & $\begin{array}{l}(3) \\
\text { Whole } \\
\text { World }\end{array}$ & $\begin{array}{l}(4) \\
\text { Whole } \\
\text { World }\end{array}$ & $\begin{array}{l}(5) \\
\text { Whole } \\
\text { World }\end{array}$ & $\begin{array}{l}(6) \\
\text { Whole } \\
\text { World }\end{array}$ & $\begin{array}{l}(7) \\
\text { Whole } \\
\text { World }\end{array}$ \\
\hline & \multicolumn{7}{|c|}{ Dependent: Estimate of Income Risk Sharing, $\widehat{\beta}_{i}$} \\
\hline $\begin{array}{l}\text { Output } \\
\text { Risk (Log) }\end{array}$ & $\begin{array}{l}-3.36 \\
(2.23)\end{array}$ & $\begin{array}{l}2.45^{\dagger} \\
(1.57)\end{array}$ & $\begin{array}{c}0.97 \\
(1.33)\end{array}$ & $\begin{array}{c}0.56 \\
(1.31)\end{array}$ & $\begin{array}{c}0.19 \\
(1.90)\end{array}$ & $\begin{array}{c}0.27 \\
(1.49)\end{array}$ & $\begin{array}{l}1.48 \\
(1.42)\end{array}$ \\
\hline $\begin{array}{l}\text { Investor } \\
\text { Protection }\end{array}$ & $\begin{array}{l}3.12 * \\
(1.60)\end{array}$ & $\begin{array}{l}1.68^{*} \\
(0.86)\end{array}$ & $\begin{array}{c}2.47 * * * \\
(0.83)\end{array}$ & $\begin{array}{l}1.69 * * \\
(0.86)\end{array}$ & $\begin{array}{c}3.71 * * * * \\
(0.97)\end{array}$ & $\begin{array}{c}2.44 * * * \\
(0.73)\end{array}$ & $\begin{array}{l}1.95^{* * *} \\
(0.81)\end{array}$ \\
\hline $\begin{array}{l}\text { GDP per capita } \\
\text { in } 1984 \text { (Log) }\end{array}$ & & & $\begin{array}{l}-0.38 \\
(0.67)\end{array}$ & & & & \\
\hline $\begin{array}{l}\text { Financial } \\
\text { Openness (Log) }\end{array}$ & & & & $\begin{array}{c}0.98 \\
(1.03)\end{array}$ & & & \\
\hline $\begin{array}{l}\text { Bank } \\
\text { Credit (Log) }\end{array}$ & & & & & $\begin{array}{l}-1.83 \\
(1.81)\end{array}$ & & \\
\hline $\begin{array}{l}\text { Stock Market Value } \\
\text { Traded (Log) }\end{array}$ & & & & & $\begin{array}{l}-0.13 \\
(0.61)\end{array}$ & & \\
\hline $\begin{array}{l}\text { Market } \\
\text { Size (Log) }\end{array}$ & & & & & & $\begin{array}{l}-0.69 \\
(0.50)\end{array}$ & \\
\hline $\begin{array}{l}\text { Control of } \\
\text { Corruption }\end{array}$ & & & & & & & $\begin{array}{c}0.32 \\
(0.59)\end{array}$ \\
\hline$R^{2}$ & 0.22 & 0.06 & 0.07 & 0.07 & 0.12 & 0.08 & 0.07 \\
\hline Observations & 47 & 70 & 117 & $84^{a}$ & $84^{b}$ & 117 & 117 \\
\hline
\end{tabular}

Notes: Dependent variable is the individual country's percentage of the idiosyncratic risk to GDP smoothed through factor income flows (the extent of income insurance, $\beta_{i}$ ) estimated as described in Section 3. All regressions include a constant and are estimated by OLS with White's correction of heteroskedasticity. Standard errors are in parentheses. *** , **, $*$, and ${ }^{\dagger}$ denote significance at $1 \%, 5 \%, 10 \%$, and $15 \%$ under null that the coefficient is zero. All the variables are sample averages. See Appendix Appendix A for detailed description of the variables. Samples: The Whole World sample includes all countries with data available for GDP per capita and the other controls in a particular specification. Equities of the economies in Financially Integrated sample are actively traded in the world capital market and included into the Morgan Stanley Capital International, Inc. benchmark world indices. Less Integrated sample contains the rest of countries from Whole World sample. ${ }^{a}$ Limited 84-country sample due to missing data on Financial Openness. ${ }^{b}$ Limited 84-country sample due to missing data on these variables, primarily for stock market. When Bank Credit and Stock Market Value Traded are included into regression separately they have negative point estimates insignificant at conventional levels; coefficient of Investor Protection has similar value and significance. 
Table 6: Explaining Income Risk Sharing: Panel GLS Regressions.

\begin{tabular}{|c|c|c|c|c|c|c|c|}
\hline & (1) & (2) & (3) & (4) & (5) & (6) & (7) \\
\hline Time Period & \multicolumn{5}{|c|}{ 1985-2004 } & 1985-1994 & 1995-2004 \\
\hline $\begin{array}{l}\text { Average Income } \\
\text { Risk Sharing }\end{array}$ & $\begin{array}{c}0.85 * * * \\
(0.35)\end{array}$ & $\begin{array}{c}1.19 * * * \\
(0.37)\end{array}$ & $\begin{array}{l}0.80^{* *} \\
(0.41)\end{array}$ & $\begin{array}{c}1.06 * * * \\
(0.43)\end{array}$ & $\begin{array}{c}0.26 \\
(0.48)\end{array}$ & $\begin{array}{l}0.57 * \\
(0.32)\end{array}$ & $\begin{array}{c}4.69 * * * \\
(0.76)\end{array}$ \\
\hline \multicolumn{8}{|c|}{ Interaction Terms with GDP Growth } \\
\hline $\begin{array}{l}\text { Output } \\
\text { Risk (Log) }\end{array}$ & $\begin{array}{l}-0.09 \\
(0.61)\end{array}$ & $\begin{array}{l}-0.10 \\
(0.45)\end{array}$ & $\begin{array}{l}-0.21 \\
(0.52)\end{array}$ & $\begin{array}{l}-0.20 \\
(0.53)\end{array}$ & $\begin{array}{l}-0.27 \\
(0.53)\end{array}$ & $\begin{array}{c}1.35 * * * \\
(0.47)\end{array}$ & $\begin{array}{l}2.18 * * \\
(0.90)\end{array}$ \\
\hline $\begin{array}{l}\text { Investor } \\
\text { Protection }\end{array}$ & $\begin{array}{c}0.61 * * * \\
(0.19)\end{array}$ & $\begin{array}{c}0.79 * * * \\
(0.19)\end{array}$ & $\begin{array}{c}0.99 * * * \\
(0.24)\end{array}$ & $\begin{array}{c}1.01 * * * \\
(0.24)\end{array}$ & $\begin{array}{c}1.07 * * * \\
(0.24)\end{array}$ & $\begin{array}{c}0.41 * * * \\
(0.16)\end{array}$ & $\begin{array}{c}1.52 * * * \\
(0.36)\end{array}$ \\
\hline Time Trend & & $\begin{array}{c}0.28 * * * \\
(0.06)\end{array}$ & & $\begin{array}{c}0.21 * * * \\
(0.08)\end{array}$ & & $\begin{array}{c}-0.21 * \\
(0.11)\end{array}$ & $\begin{array}{c}1.39 * * * \\
(0.28)\end{array}$ \\
\hline $\begin{array}{l}\text { Post-Transition } \\
\text { (1995) Period }\end{array}$ & & & & & $\begin{array}{l}1.83 * * \\
(0.84)\end{array}$ & & \\
\hline \multicolumn{8}{|c|}{ Linear Terms } \\
\hline $\begin{array}{l}\text { Output } \\
\text { Risk (Log) }\end{array}$ & $\begin{array}{c}0.02 \\
(0.02)\end{array}$ & $\begin{array}{c}0.02 \\
(0.02)\end{array}$ & $\begin{array}{c}0.02 \\
(0.02)\end{array}$ & $\begin{array}{c}0.02 \\
(0.02)\end{array}$ & $\begin{array}{c}0.02 \\
(0.02)\end{array}$ & $\begin{array}{c}0.00 \\
(0.00)\end{array}$ & $\begin{array}{c}0.02 \\
(0.03)\end{array}$ \\
\hline $\begin{array}{l}\text { Investor } \\
\text { Protection }\end{array}$ & $\begin{array}{l}0.01^{\dagger} \\
(0.01)\end{array}$ & $\begin{array}{l}0.02 * * \\
(0.01)\end{array}$ & $\begin{array}{c}0.01 \\
(0.01)\end{array}$ & $\begin{array}{c}0.01 \\
(0.01)\end{array}$ & $\begin{array}{c}0.01 \\
(0.01)\end{array}$ & $\begin{array}{c}0.00 \\
(0.00)\end{array}$ & $\begin{array}{c}0.03 * * * \\
(0.01)\end{array}$ \\
\hline $\begin{array}{l}\text { Post-Transition } \\
\text { (1995) Period }\end{array}$ & & & & & $\begin{array}{c}0.00 \\
(0.02)\end{array}$ & & \\
\hline $\begin{array}{l}\text { Country Fixed Effects } \\
R^{2}\end{array}$ & $\begin{array}{c}\text { no } \\
0.06\end{array}$ & $\begin{array}{c}\text { no } \\
0.07\end{array}$ & $\begin{array}{c}\text { yes } \\
0.08\end{array}$ & $\begin{array}{c}\text { yes } \\
0.08\end{array}$ & $\begin{array}{c}\text { yes } \\
0.08\end{array}$ & $\begin{array}{c}\text { yes } \\
0.25\end{array}$ & $\begin{array}{c}\text { yes } \\
0.16\end{array}$ \\
\hline
\end{tabular}

Notes: Results are from the following GLS regression: $\widetilde{g d p}_{i t}-\widetilde{g n i}_{i t}=\alpha_{t}+\nu_{i}+\widehat{\beta g d p_{i t}}+\mathbf{X}_{i}^{\prime} \delta+\varepsilon_{i t} . \Delta \log g d p_{i t}$ is the growth rate of real per capita GDP; $\widetilde{g d p} p_{i t}$ is $\Delta \log g d p_{i t}$ minus the growth rate of the "world" real per capita GDP. $\widetilde{g n i}_{i t}$ is defined similarly using the growth rate of real per capita GNI. In this regression $\beta=\beta_{0}+\beta_{1}\left(\operatorname{risk}_{i t}-\overline{\text { risk }}_{t}\right)+$ $\beta_{2}\left(\operatorname{inv}_{i t}-\overline{\operatorname{inv}}_{t}\right)+\beta_{3}(t-\bar{t})$. risk $i t$ is Output Risk of country $i$ at time $t$. $\overline{\text { risk }}_{t}$ is the (un-weighted) average across countries of Output Risk at time $t$. inv $v_{i t}$ is Investor Protection of country $i$ at time $t$. $\overline{\operatorname{inv}}_{t}$ is the (un-weighted) average across countries of Investor Protection at time $t . t$ is the time trend and $\bar{t}$ is the middle year of the sample period. The "linear term" $\mathbf{X}_{i}$ consists of $\left(\operatorname{risk}_{i t}-\overline{\operatorname{risk}}_{t}\right)$ and $\left(\operatorname{inv}_{i t}-\overline{\operatorname{inv}}_{t}\right)$. Standard errors are in parentheses. ***, **, *, and ${ }^{\dagger}$ denote significance at $1 \%, 5 \%, 10 \%$, and $15 \%$ under null that the coefficient is zero. Coefficients and standard errors are multiplied by 100 . The estimated value of $\beta_{0}$ reported in the first line of the table corresponds to the average amount of income risk sharing (in percent) within the group. $\beta$ measures the amount of income risk sharing obtained in period $t$ by country $i$ with the value of Output Risk equal to risk $i t$ and the value of Investor Protection equal to inv $i t$. Post-Transition (1995) Period is the binary variable taking the value of 1 from 1995-onward, and zero otherwise. Time fixed effects and country fixed effects (when included) are not reported. See Appendix A for detailed description of the variables and Table 2 for descriptive statistics. Samples: The Whole World sample (117-countries) includes all countries with data available for GDP per capita and Institutional Quality. The panel is estimated using 2,340 observations for 1985-2004, 1,150 observations for 1985-1994, and 1,170 observations for 1995-2004. 
Table 7: Explaining Consumption Risk Sharing: Panel GLS Regressions.

(7) 1985-1994

1995-2004

$\begin{array}{lccccccc}\text { Average Consumption } & 24.3 * * * & 24.7 * * * & 27.9 * * * & 27.8 * * * & 27.0 * * * & 31.8 * * * & 37.2^{* * * *} \\ \text { Risk Sharing } & (0.94) & (0.95) & (1.01) & (1.03) & (1.22) & (1.25) & (1.67)\end{array}$

Interaction Terms with GDP Growth

\begin{tabular}{|c|c|c|c|c|c|c|c|}
\hline $\begin{array}{l}\text { Output } \\
\text { Risk (Log) }\end{array}$ & $\begin{array}{l}-1.21 \\
(1.18)\end{array}$ & $\begin{array}{l}-1.25 \\
(1.19)\end{array}$ & $\begin{array}{c}0.60 \\
(1.37)\end{array}$ & $\begin{array}{c}0.60 \\
(1.37)\end{array}$ & $\begin{array}{c}0.60 \\
(1.38)\end{array}$ & $\begin{array}{c}2.77 \\
(1.96)\end{array}$ & $\begin{array}{c}-4.87 * * \\
(2.14)\end{array}$ \\
\hline $\begin{array}{l}\text { Investor } \\
\text { Protection }\end{array}$ & $\begin{array}{c}3.34 * * * \\
(0.47)\end{array}$ & $\begin{array}{c}3.56 * * * \\
(0.48)\end{array}$ & $\begin{array}{c}4.32 * * * \\
(0.52)\end{array}$ & $\begin{array}{c}4.35 * * * \\
(0.53)\end{array}$ & $\begin{array}{c}4.54 * * * \\
(0.53)\end{array}$ & $\begin{array}{c}6.28 * * * \\
(0.58)\end{array}$ & $\begin{array}{c}5.04 * * * \\
(0.83)\end{array}$ \\
\hline Time Trend & & $\begin{array}{c}0.11 \\
(0.17)\end{array}$ & & $\begin{array}{l}-0.12 \\
(0.20)\end{array}$ & & $\begin{array}{c}-1.23 * * * \\
(0.40)\end{array}$ & $\begin{array}{c}3.39 * * * \\
(0.65)\end{array}$ \\
\hline $\begin{array}{l}\text { Post-Transition } \\
\text { (1995) Period }\end{array}$ & & & & & $\begin{array}{l}3.27^{\dagger} \\
(2.13)\end{array}$ & & \\
\hline \multicolumn{8}{|c|}{ Linear Terms } \\
\hline $\begin{array}{l}\text { Output } \\
\text { Risk (Log) }\end{array}$ & $\begin{array}{l}0.10^{* *} \\
(0.05)\end{array}$ & $\begin{array}{l}0.10 * * \\
(0.05)\end{array}$ & $\begin{array}{l}0.09 * \\
(0.05)\end{array}$ & $\begin{array}{l}-0.09 * \\
(0.05)\end{array}$ & $\begin{array}{l}0.09 * \\
(0.05)\end{array}$ & $\begin{array}{c}0.00 \\
(0.00)\end{array}$ & $\begin{array}{l}0.10^{*} \\
(0.06)\end{array}$ \\
\hline $\begin{array}{l}\text { Investor } \\
\text { Protection }\end{array}$ & $\begin{array}{c}-0.11 * * * \\
(0.02)\end{array}$ & $\begin{array}{c}-0.11 * * * \\
(0.00)\end{array}$ & $\begin{array}{c}-0.04 * * \\
(0.02)\end{array}$ & $\begin{array}{c}-0.04 * * \\
(0.02)\end{array}$ & $\begin{array}{c}-0.05 * * \\
(0.02)\end{array}$ & $\begin{array}{c}0.00 \\
(0.00)\end{array}$ & $\begin{array}{c}-0.04 * \\
(0.02)\end{array}$ \\
\hline $\begin{array}{l}\text { Post-Transition } \\
\text { (1995) Period }\end{array}$ & & & & & $\begin{array}{c}0.01 \\
(0.06)\end{array}$ & & \\
\hline $\begin{array}{l}\text { Country Fixed Effects } \\
R^{2}\end{array}$ & no & no & yes & yes & yes & yes & yes \\
\hline$R^{2}$ & 0.32 & 0.33 & 0.32 & 0.32 & 0.32 & 0.48 & 0.39 \\
\hline
\end{tabular}

Notes: Results are from the following GLS regression: $\widetilde{g d p}_{i t}-\widetilde{\operatorname{tcons}}_{i t}=\alpha_{t}+\nu_{i}+\beta \widetilde{\beta g d p_{i t}}+\mathbf{X}_{i}^{\prime} \delta+\varepsilon_{i t} . \Delta \log g d p_{i t}$ is the growth rate of real per capita GDP; $\widetilde{g d p} p_{i t}$ is $\Delta \log g d p_{i t}$ minus the growth rate of the "world" real per capita GDP. $\widetilde{\text { tcons }}_{i t}$ is defined similarly using the growth rate of real per capita final consumption expenditure. In this regression $\beta=\beta_{0}+\beta_{1}\left(\operatorname{risk}_{i t}-\overline{\operatorname{risk}}_{t}\right)+\beta_{2}\left(\operatorname{inv}_{i t}-\overline{\operatorname{inv}}_{t}\right)+\beta_{3}(t-\bar{t})$. risk $i t$ is Output Risk of country $i$ at time $t$. $\overline{\operatorname{risk}}_{t}$ is the (un-weighted) average across countries of Output Risk at time $t . \operatorname{inv}_{i t}$ is Investor Protection of country $i$ at time $t$. $\overline{\operatorname{inv}}_{t}$ is the (un-weighted) average across countries of Investor Protection at time $t . t$ is the time trend and $\bar{t}$ is the middle year of the sample period. The "linear term" $\mathbf{X}_{i}$ consists of $\left(\operatorname{risk}_{i t}-\overline{\operatorname{risk}}_{t}\right)$ and $\left(\operatorname{inv}_{i t}-\overline{\operatorname{inv}}_{t}\right)$. Standard errors are in parentheses. $* * *, * *, *$, and ${ }^{\dagger}$ denote significance at $1 \%, 5 \%, 10 \%$, and $15 \%$ under null that the coefficient is zero. Coefficients and standard errors are multiplied by 100 . The estimated value of $\beta_{0}$ reported in the first line of the table corresponds to the average amount of consumption risk sharing (in percent) within the group. $\beta$ measures the amount of consumption risk sharing obtained in period $t$ by country $i$ with the value of Output Risk equal to risk $i_{i t}$ and the value of Investor Protection equal to inv $i t$. Post-Transition (1995) Period is the binary variable taking the value of 1 from 1995-onward, and zero otherwise. Time fixed effects and country fixed effects (when included) are not reported. See Appendix A for detailed description of the variables. Samples: The Whole World sample (117-countries) includes all countries with data available for GDP per capita and Institutional Quality. The panel is estimated using 2,340 observations for 1985-2004, 1,150 observations for 1985-1994, and 1,170 observations for 1995-2004. 
Figure 1: Country Estimates of Income Risk Sharing

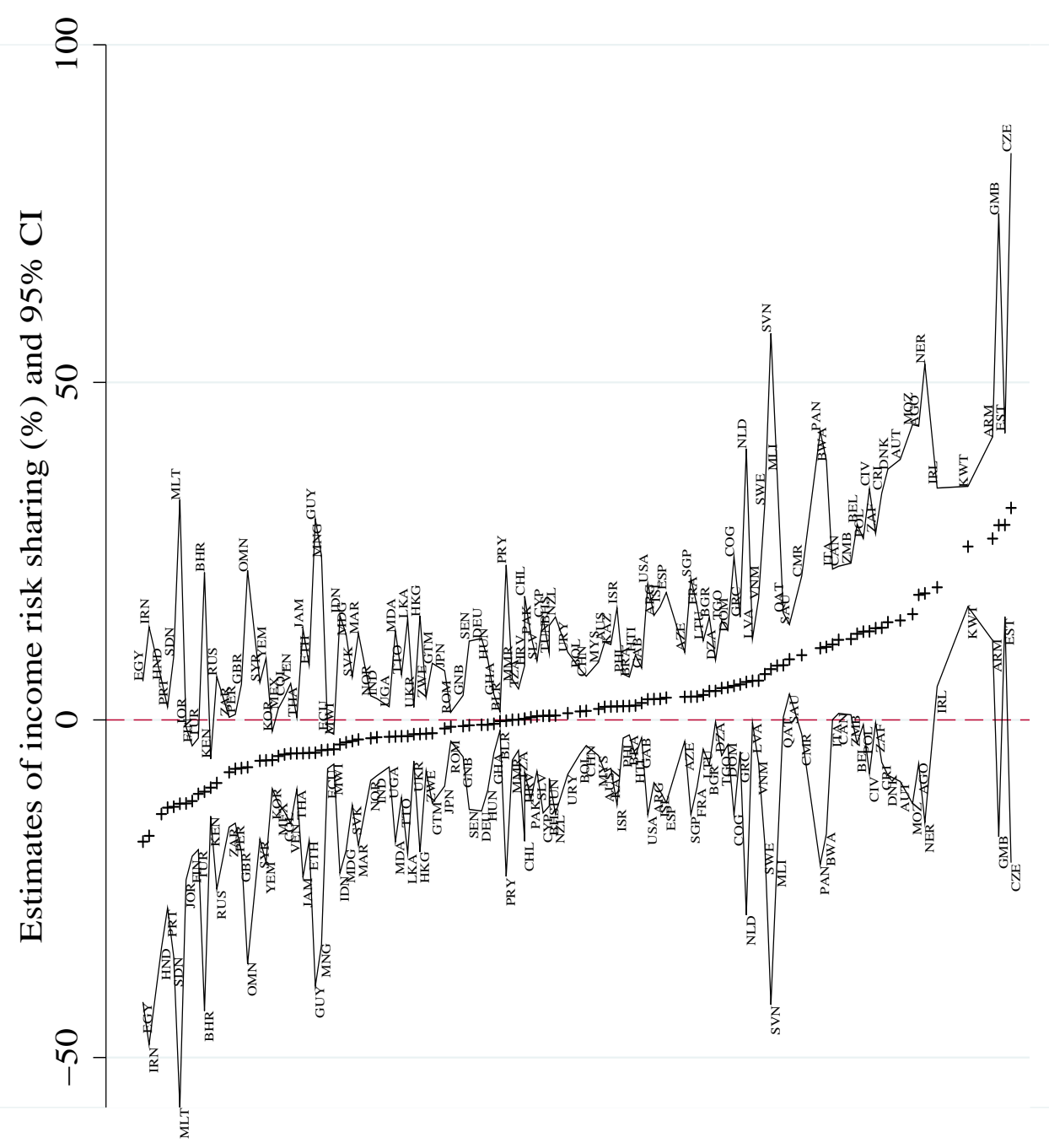

Notes: The figure plots the estimates of income risk sharing, $\widehat{\beta}_{i}$ from Eq. (5), denoted by “+”, using 117-country Whole World sample. Thin solid line represents $95 \%$ confidence interval. 
Figure 2: Partial Correlation Plot: Income Risk Sharing versus Investor Protection Controlling for Output Risk

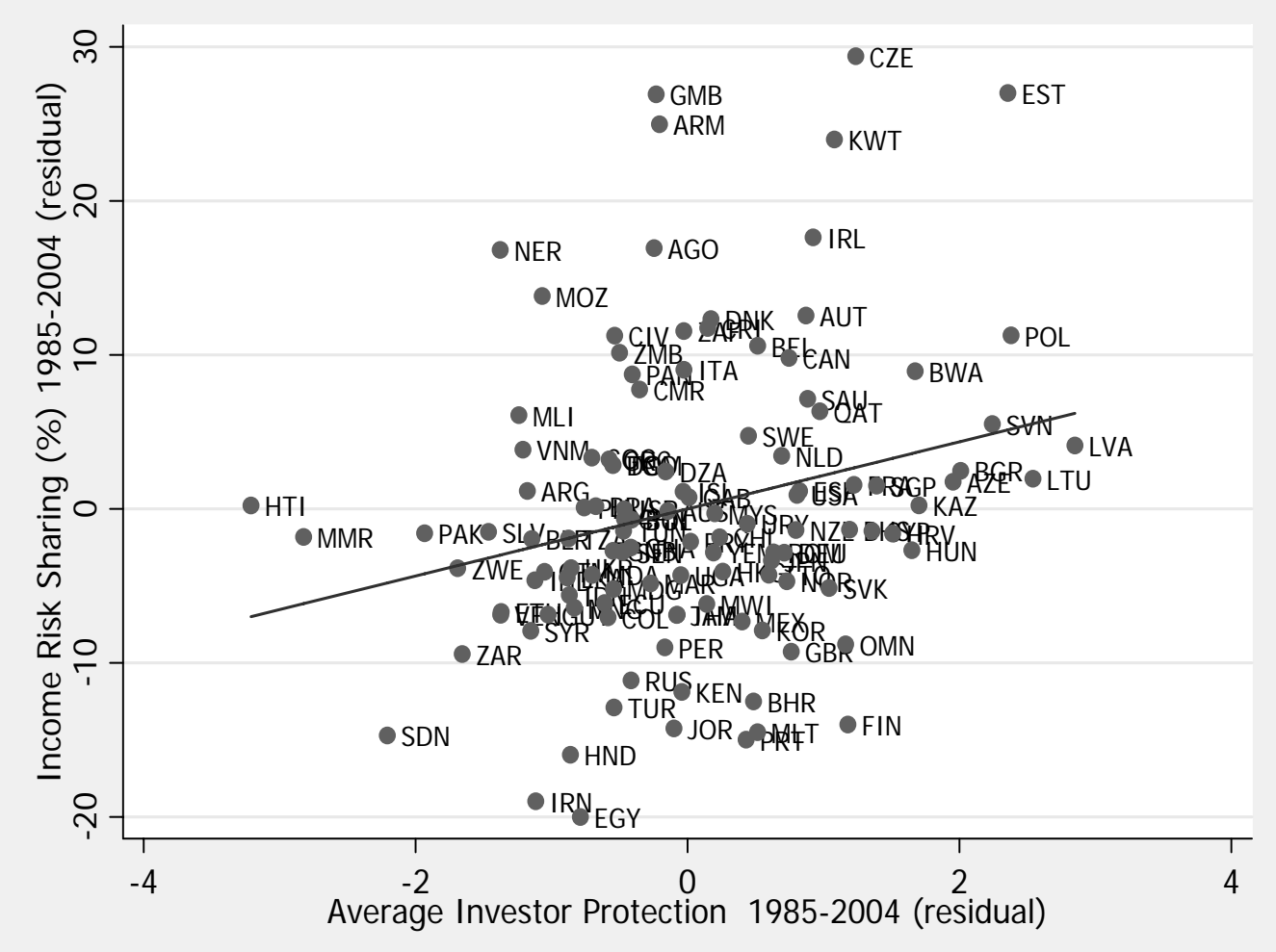

Notes: The figure plots the residuals from the OLS regression of the estimates of income risk sharing, $\widehat{\beta}_{i}$, on Output Risk versus the residuals from the regression of Investor Protection on Output Risk in 117-country Whole World sample; a constant is included in both regressions. The line represents the regression line of one set of residuals versus another. 
Figure 3: Extent of Income Risk Sharing in Equilibrium $\beta$ as a Function of Idiosyncratic Risk $\phi$ and Cross-Border Barriers to Capital Mobility $\tau(\%)$

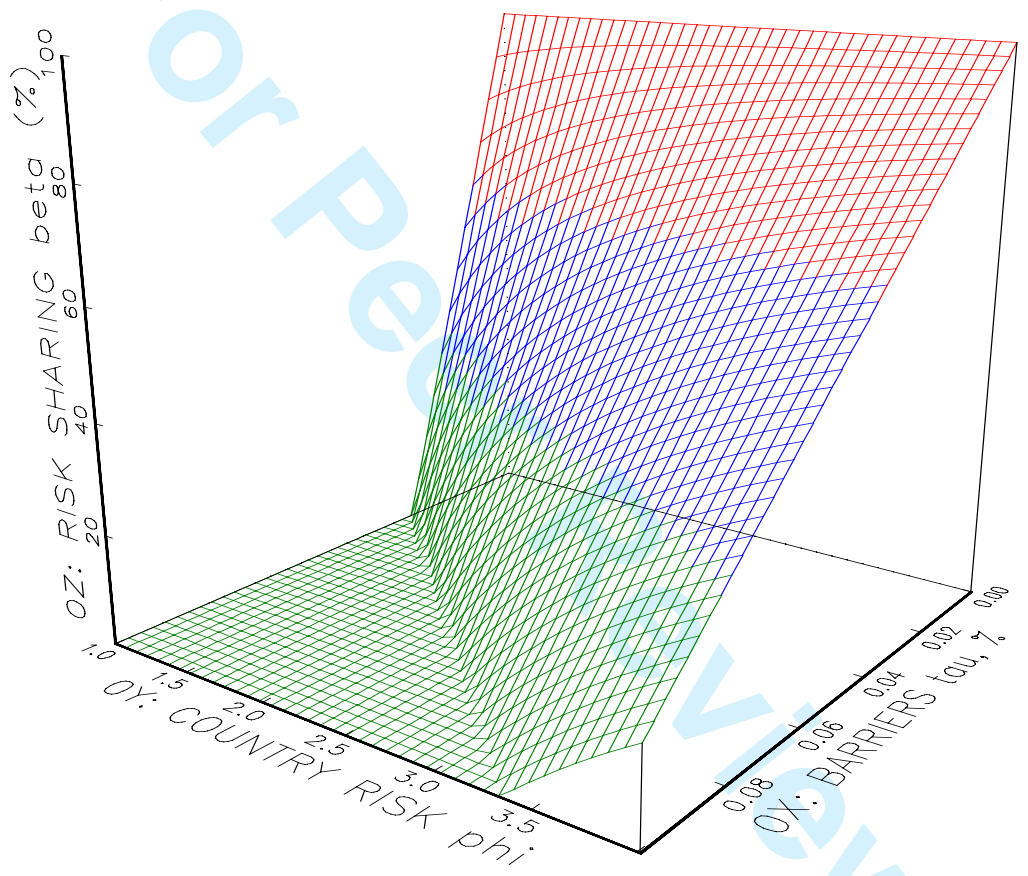

Notes: The figure represents percentage of income insurance $(\beta)$ from the idiosyncratic risk as a function of cross-border barriers to capital mobility $\tau(\%)$ and domestic output risk $\phi . \beta$ is represented by Eq. (3). It measure the extent of income risk sharing compared to full risk sharing. 